\title{
The carrying capacity and the effects of protection level in three marine protected areas in the Balearic Islands (NW Mediterranean)
}

\author{
JOSEP COLL ${ }^{1,2}$, ANTONI GARCIA-RUBIES $^{3}$, GABRIEL MOREY $^{1,2}$ \\ and ANTONI M. GRAU ${ }^{1}$ \\ ${ }^{1}$ Direcció General de Medi Rural i Marí, Govern de les Illes Balears, c/ Foners, 10, 07006 Palma de Mallorca, Spain. \\ E-mail: jcoll@dgpesca.caib.es \\ 2 Tragsatec, c/ Fluvià, 1, 07009 Palma de Mallorca, Spain. \\ ${ }^{3}$ Centre d'Estudis Avançats de Blanes, CSIC, Acc. Cala Sant Francesc, 14, 17300 Blanes, Spain.
}

\begin{abstract}
SUMMARY: The monitoring of fisheries target species in three marine protected areas (MPAs) located in the NW Mediterranean provided important conclusions on management effects. The abundance, occurrence and biomass of large fish showed consistent and growing trends inside the MPAs. Fish diversity was also favoured by protection. Nevertheless, spatial variance of these indicators at a medium scale was often of the same order as that caused by time between different protection levels. The carrying capacity was determined for the first time in western Mediterranean MPAs in five out of six sites studied, and in all cases it was achieved within the first five years of protection. The observed values indicate that the system of the studied MPAs is representative of the general coastal environment of the Balearic Islands, but is far from the potential of other MPAs which are considered as hot spots in other localities. Likewise, this study shows that partially protected areas can also be fairly effective if their habitats fit with those required by target species and fishing modalities are suitably regulated or banned.
\end{abstract}

Keywords: Mediterranean, MPAs, fish, no-take areas, carrying capacity, buffer areas.

RESUMEN:CAPACIDADDECARGA Y EFECTOSDEL NIVELDE PROTECCIÓNENTRESAMPSDELASISLASBALEARES(MEDITERRÁNEO NorOCCIDENTAL). - El seguimiento de especies de peces vulnerables a la pesca en 3 AMPs del Mediterráneo Occidental ha permitido extraer conclusiones importantes sobre los efectos de la gestión. La abundancia y ocurrencia de peces grandes asî como la biomasa presentaron patrones temporales consistentes y crecientes en las AMPs. Conjuntamente al incremento de biomasa, la diversidad de peces también aumentó con la protección. Sin embargo, la varianza de estos indicadores a mediana escala espacial fue a menudo del mismo orden que la producida por el tiempo y el nivel de protección. La capacidad de carga se ha establecido por primera vez en AMPs del Mediterráneo Occidental en 5 de los 6 sitios estudiados. En todos los casos esta situación se alcanzó dentro de los primeros 5 años de protección. Los resultados indican que el sistema de AMPs estudiado es representativo de la mayor parte de las costas de Baleares pero que está lejos del potencial de otras AMPs consideradas como hot spots en otros enclaves geográficos. Asimismo, este trabajo pone de manifiesto que las áreas de reserva parcial pueden ser muy efectivas si su hábitat se ajusta al de las especies que quieren protegerse y si las modalidades de pesca restringidas o prohibidas son las adecuadas.

Palabras clave: Mediterráneo, AMPs, peces, reservas integrales, capacidad de carga, reservas parciales.

\section{INTRODUCTION}

Over the last few decades the number of marine protected areas (MPAs) has constantly increased (Wood et al. 2008) as a response to warnings made by many authors about over-fishing and possible collapse of a large number of fisheries worldwide (FAO 1995, Jackson et al. 2001, Worm et al. 2006, Mora et al. 2009). MPAs are generally created with the dual purpose of conservation and fisheries management, and are useful 
tools for ecosystem management of marine resources (Agardi 2005, Angulo-Valdes and Hatcher 2010).

In the Mediterranean there are currently about 100 MPAs, most of which have been created since the 1980s mainly around the northern coast (Abdulla et al. 2008). Despite this general increase, some authors have described major problems that need to be solved, such as MPA habitats not being entirely representative, the high level of isolation and the need for more effective surveillance and monitoring (Reñones et al. 1998; Abdulla et al. 2008, Guidetti et al. 2008).

The Balearic Islands are no exception to the general increase in MPAs. In 1997, within the framework of fisheries legislation, the autonomous government issued Decree 91/1997 for the protection of marine resources in waters under its jurisdiction (BOCAIB, No 89, 17/07/1997). Since then, seven fishery MPAs have been created in the Balearic Islands, with a total protected area of $49587 \mathrm{ha}, 7.3 \%$ of which has full protection (hereafter called no-take areas).

Within the Balearic Islands MPAs, habitats are protected by eliminating or regulating the more aggressive fishing methods (e.g. bottom trawling), and extracting sand for beach regeneration and anchoring in seagrass meadows is also prohibited. Species that appear on red lists are protected (Mayol et al. 2000; Annexe IV of Habitats Directive 92/43/EEC). However, the main purposes of the MPAs are related to fisheries goals: a) to provide safe sites with maximum protection where species can attain a more natural demographic structure with a higher proportion of older individuals with greater reproductive capacity (Plan Development Team 1990; Berkeley et al. 2004; Reñones et al. 2010); and b) to test the response of the buffer areas around the notake areas, which have different regulations for fishing effort and gear and could benefit from the export of biomass from the no-take areas (Goñi et al. 2008, Harmelin-Vivien et al. 2008, Forcada et al. 2009).

In the Balearic Islands the demand for new MPAs continues to grow, especially from the professional fishing industry and the tourism industry (three and two of the seven MPAs were created at the request of the fishing and tourism industries, respectively); thus, there is an increasing need for assessments of MPAs to provide references for decision makers. Now, with the experience gained over the last 10 years, the challenges in providing information and guidance to stakeholders and the fisheries authorities are based on three main aspects: a) predicting the time needed for target species to recover in the no-take areas in order to determine when a possible spillover can be expected, either as a consequence of density-dependent processes (SánchezLizaso et al. 2000, Jennings 2001, Grüss et al. 2011) or due to the larger home ranges of bigger fish (Palumbi 2004, Barret et al. 2007, Grüss et al. 2011); b) determining the carrying capacity in the no-take areas to obtain reference values and provide data for fisheries models in order to achieve sustainable yields in similar ecosystems (Pauly 1984, Clarck 1990); and c) deter- mining which management measures applied in the buffer areas have been effective, and which have not.

In the scientific literature there is a wide range of results regarding the effect of the protection time on the recovery of resources. Thus, there are varying descriptions: quick recoveries of less than five years (Côté et al. 2001, McClanahan and Arthur 2001, Halpern and Warner 2002); linear models for species with different maximum sizes (Molloy et al. 2009) or for specific top predator species (McClanahan 2000) with estimated recovery times of between 15 and 30 years; exponential models involving decades or human intergenerational time scales for the recovery of some target species (Russ and Alcala 1996, 2004; García-Charton et al. 2008); cases of biomass saturation for well defined species between 10 and 37 years of protection (McClanahan et al. 2007, 2009); and even cases in which the total biomass increases and then decreases due to cascade effects, intense fishing activities in the surrounding waters or ontogenic migration out of the protected area (Barret et al. 2007, McClanahan et al. 2007).

Given this wide range of responses to the protection time, concepts derived from the social and human sciences, such as the "idiosyncrasy" of each reserve, have been adopted to describe this multifactorial problem with many, very local interactions (Guidetti and Sala 2007, McClanahan et al. 2009). Though it has been necessary to resort to these concepts, much of the diversity and conflict between the results is due to the methodological approach, as many studies are metaanalyses of geographically separated MPAs that use chronosequences (i.e. the protection time is replaced with specific cases of different reserves of different ages). Russ et al. (2005) and McClanahan et al. (2009) warn of the risk of confusing the effect of protection time with the chronosequences that do not take into account significant geographical differences, habitats, fishing intensity in the surrounding waters, socioeconomic aspects, management quality and, above all, the history of poaching in each reserve. These authors recommend continuing the long-term monitoring of specific reserves where these factors are known.

In this framework, the specific objectives of this study were to use the data obtained from continuous monitoring of three marine reserves in the Balearic Islands to: a) compare the effects of the protection level (no-take areas vs. buffer areas vs. fished areas) and the influence of habitat on a series of indicators calculated for the fisheries target species; and b) determine whether the no-take areas have achieved or are on the way to achieving the carrying capacity of the system.

\section{MATERIALS AND METHODS}

\section{Study areas}

This paper focuses on the three oldest fishery MPAs in the waters around the Balearic Islands. They were created in 1999, but enforcement and monitoring 


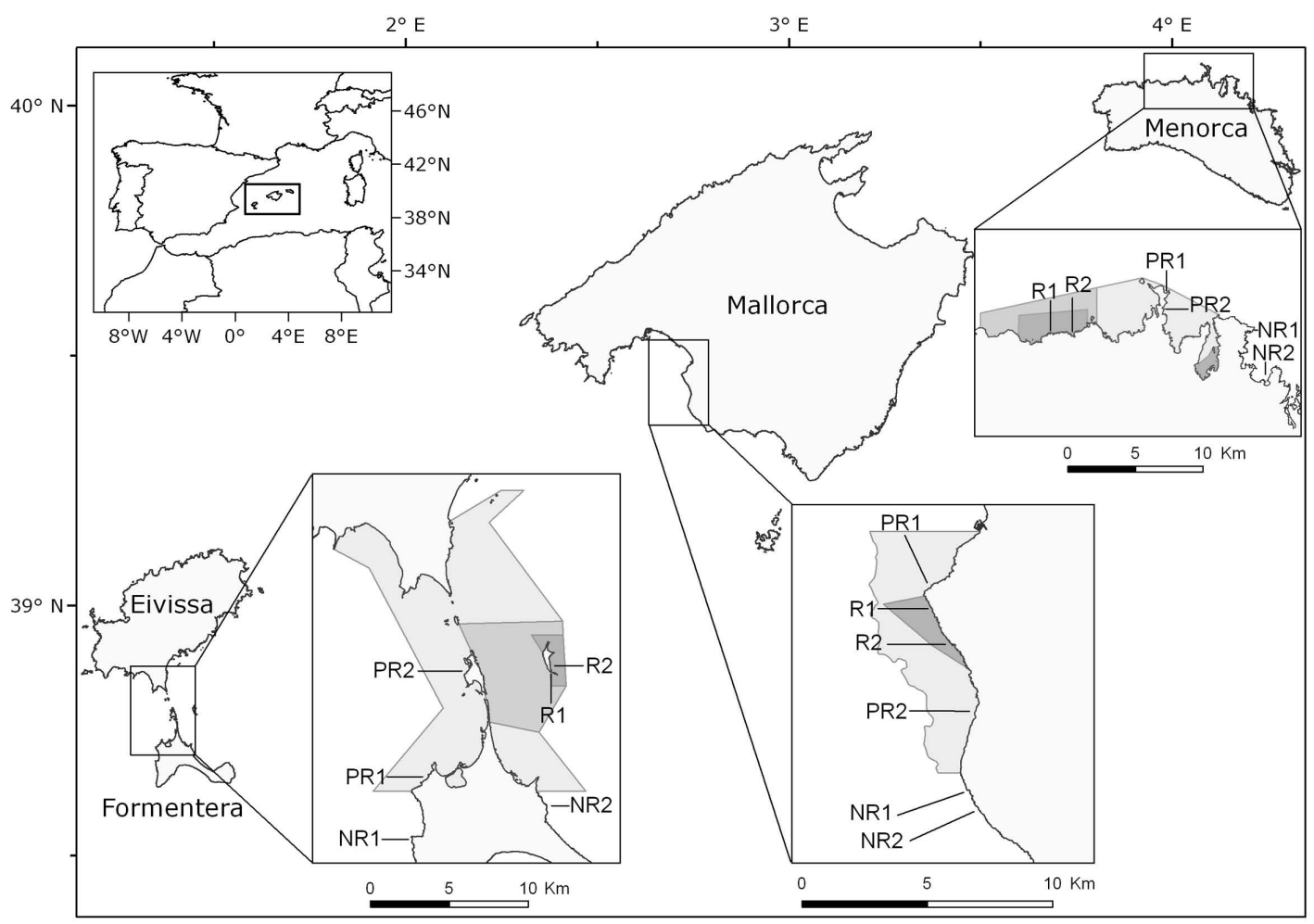

FIG. 1. - Location and zoning of Freus of the Ibiza and Formentera Marine Reserve (FMR), Palma Bay Marine Reserve (PMR) and North Menorca Marine Reserve (NMMR). The three tones of grey correspond to a gradient from maximum protection R, no-take area (dark grey), to PR, partial protection (lighter greys). The non-protected area NR is shown in white. Numbers 1 and 2 specify two different sites within each protection level.

did not start until 2000. These MPAs can currently be considered level 5 or institutionalized according to the classification in White et al. (2006), which depends on time since protection began, enforcement and the government's commitment to the protected area. All the MPAs include an area with maximum protection, or no-take area, where all fishing and diving are completely prohibited. In the rest of the MPA, which we call a partial reserve or buffer area, trawling and purseseining are prohibited while some forms of small-scale commercial fishing and recreational fishing are allowed under more restrictive conditions compared with open fishing areas. All the permitted forms of recreational fishing have a quota of 5 kilos plus one fish per fisher per day and a maximum of one fish for some vulnerable species.

The Ibiza and Formentera Marine Reserve (FMR) in "Els Freus" is located in the south of the Balearic Islands and encompasses an area of 13717 ha, of which 403 ha are a no-take area. In the partial reserve, spearfishing is prohibited and there is a permanent ban on recreational fishing in a part of the buffer zone alongside the no-take area (Fig. 1). The trammel net is the main gear of the commercial fleet operating in the area. The fleet consists of 16 vessels in Formentera and 24 vessels in Ibiza. Recreational fishers mainly use hook and line, trolling and jigging for squid. Most of the seabed in this MPA is covered by Posidonia oceanica meadows, fine sand and coastal detrital sediments. Rocky seabeds occupy only 428 ha, mostly in the first $25 \mathrm{~m}$ depth.

The Marine Reserve of Palma Bay (PMR) is located on the NE side of Palma Bay on the island of Mallorca, and encompasses a total area of 2394 ha. The original no-take area occupied 208 ha, but in 2006 this was increased towards the north and south to make a total of 282 ha (Fig. 1). The commercial fleet from the port of Palma is constituted by 24 small-scale vessels which mainly fish with trammel and gill nets in the PMR. Since 2006 there has been a nine-month ban on fishing with trammel nets within two-thirds of the MPA in its southern part. Recreational fishers are only permitted to fish four days a week with the following gears: hook and line, trolling, jigging for squid and coastal rods with an established minimum hook size. Palma Marine Reserve is the only one of the three MPAs studied in which spearfishing is permitted; however, this activity is restricted to four days a week with a quota for the most vulnerable species. Most of the seabed is covered by the seagrass Posidonia oceanica, sand and detrital sediment. The rocky area only occupies 92 ha in the shallower coastal belt, mainly in the first $15 \mathrm{~m}$ depth.

The North Menorca Marine Reserve (NMMR) is located on the north side of the most northern island of the Balearic Archipelago. It extends for 5199 ha, 838 of which are a no-take area. Another smaller no-take area of 217 ha is located on soft seabeds on the eastern 
side, in the largest bay of the MPA (Fig. 1). In the partial reserve, 12 vessels fish commercially with trammel nets, long-lines and gill nets. Recreational fishers use hook and line, trolling and coastal rods; however, recreational fishing is totally prohibited in a part of the buffer zone surrounding the no-take area (Fig. 1). This MPA has the largest proportion of rocky bottoms, which cover 2447 ha. These are not only restricted to the coastal belt as the rock continues from the shore to more than $45 \mathrm{~m}$ depth at many sites. The other major bottom types are fine sand and the seagrass Posidonia oceanica, which mainly grows on rocky substrata.

The descriptions for the seabed types in each MPA come from detailed bionomic maps made by Ballesteros and Cebrian (2004) at the beginning of the monitoring period.

\section{Sampling design}

The three MPAs are found in the same biogeographic milieu and no differences in the ichthyofauna have been described among them (Cardona 2002). However, as they are more than $150 \mathrm{~km}$ apart and there are sufficient differences in habitat conditions, size, historical exploitation of the island where they are located and the legislation within each partial reserve, they were analysed independently. This separate treatment is also justified because the sampling times did not always coincide in the three MPAs.

For each MPA and its surroundings we compared three protection levels: a) $\mathrm{R}$, maximum protection or no-take area; b) PR, partial reserve with restricted commercial and recreational fishing; and c) NR, nonreserve control areas outside the MPA where fishing is permitted. To take into account sources of variation on medium spatial scales (hundreds to thousands of metres) (García-Charton et al. 2004), two random sites on rocky seabeds were chosen within each protection level in each MPA: R1, R2, PR1, PR2, NR1 and NR2. Eighteen transects, used as count units, were censused at each site at each sampling time for FMR and NMMR, with the exception of Sampling 1 in the NMMR, where, due to weather conditions, only nine transects were censused. In the PMR, where there is less rocky habitat than in the other MPAs, only nine transects per site and sampling time were censused.

All surveys were carried out between late spring and late summer. The sampling times were: T1, 2000; T2, 2000; T3, 2001; T4, 2002; T5, 2003; T6, 2003; T7, 2006; T8, 2009 ( $\mathrm{N}=864)$ for the FMR; T1, 2000; T2, 2001; T3, 2002; T4, 2003; T5, 2005 and T6, 2008 $(\mathrm{N}=324)$ for PMR and T1, 2000; T2, 2000; T3, 2001; T4, 2002; T5, 2003; T6, 2003; T7, 2005 and T8, 2007 $(\mathrm{N}=810)$ for the NMMR.

\section{Data collection}

Fish and habitat data were collected through visual censuses carried out by scuba divers. The sample unit or count unit was a transect of $50 \times 5 \mathrm{~m}\left(250 \mathrm{~m}^{2}\right)$ marked out on the seafloor with a tape as the diver swam forward. Each transect was sampled by a single diver who focused on a rocky fish assemblage targeted by commercial, speargun and surface-recreational fishing. This fish assemblage is characterized by having small home ranges which correspond to spatial categories 3,5 and 6 described by Harmelin (1987). Focusing the census on such a reduced group of species improves the accuracy of the census, as Greene and Alevizon (1989) demonstrated with discrete group censusing. Moreover, it is less timeconsuming and allows a greater number of count units to be carried out than censusing the entire fish community. All the divers were experts in determining fish species, and the census process and size estimations were carried out after the divers had undergone training protocols with artificial fish distributions (Bell et al. 1985). All transects were haphazardly distributed, always on rocky substrata between 3 and $15 \mathrm{~m}$ depth and with a distance greater than $20 \mathrm{~m}$ between contiguous transects.

As the divers returned they picked up the tape, and the portion of tape that each type of habitat occupied was recorded: (SB) small rocky blocks $(\varnothing<1 \mathrm{~m}),(\mathrm{MB})$ medium rocky blocks $(1<\varnothing<2)$, (LB) large rocky blocks $(\varnothing>2)$, (HR) homogeneous rock, (S) sand and (POS) Posidonia oceanica. The depth of the transects was kept as constant as possible, and the minimum and maximum depths were always recorded. The topographical complexity of the seabed was estimated as a proxy of the rugosity as described by Luckhurst and Luckhurst (1978) and the slope of the transect. This proxy of rugosity is a semi-quantitative variable that was scaled from a minimum of 1 to a maximum of 4 based on a scale that has been used previously by other authors (Ordines et al. 2005). The slope is also a semi-quantitative variable, but is ranked locally on the transversal inclination of the transect: 1 , inclination less than $30^{\circ} ; 2$, from 30 to $60^{\circ} ; 3$, from $60^{\circ}$ to $90^{\circ}$; and 4 , for caves and overhangs.

\section{Data analysis}

\section{Study of the effects of protection}

Five synthetic indicators were calculated for each transect based on the density data and specific sizeweight relationships (Morey et al. 2003), where $\mathrm{Bt}$ is the total biomass ( $\mathrm{g}$ of total wet weight $250 \mathrm{~m}^{-2}$ ), St is fish richness (i.e. number of species), Dt is total density of fish, $S_{20}$ is number of species when fish size was greater than $20 \mathrm{~cm}$, and $D_{20}$ is fish density when fish size was greater than $20 \mathrm{~cm}$. The threshold of $20 \mathrm{~cm}$ was selected because it is over the mean legal size for most fish and between one-third and two-thirds of the maximum size of most target species dealt with here, except for Serranidae and eelfish, which normally occur at low densities. Therefore, this threshold value allowed us to analyse the fraction of the population corresponding to the medium and large fish for most species. 
When the different fish families in an MPA were well represented at the different sampling times, the biomass per family was also used as an indicator. Given that the families Muraenidae and Congridae share very similar habitats and ecological niches, they were grouped together in the eelfish guild. The trophic level for each species was determined using www.fisbase. org (Froese and Pauly 2000).

The values of these indicators were treated as dependent variables in a mixed hierarchical ANOVA design with three factors: protection $(\mathrm{P})$, fixed and with three levels ( $\mathrm{R}, \mathrm{PR}$ and $\mathrm{NR})$; site $(\mathrm{S})$, random and nested within protection $\mathrm{S}(\mathrm{P})$; and time $(\mathrm{T})$, fixed and corresponding to each sampling time. The linear model of this ANOVA is represented with the equation: $\mathrm{X}_{\mathrm{ijk}}=\mu+\mathrm{P}_{\mathrm{i}}+\mathrm{T}_{\mathrm{j}}+\mathrm{S}(\mathrm{P})_{\mathrm{k}(\mathrm{i})}+\mathrm{T} \times \mathrm{P}_{\mathrm{ij}}+\mathrm{T} \times \mathrm{S}(\mathrm{P})_{\mathrm{jk}(\mathrm{i})}+$ Error $_{1(\mathrm{ijk})}$, where $\mathrm{X}_{\mathrm{ijkl}}$ is the value of an indicator within a transect (1) from a site $(\mathrm{k})$ at a time $(\mathrm{j})$ and protection level (i), while $\mu$ is the overall mean.

As this study began almost when the three MPAs were first established and enforced, any different evolution over time under a specific protection level can be considered a significant $\mathrm{T} \times \mathrm{P}$ interaction if the response between sites is homogeneous, or the interaction $\mathrm{T} \times \mathrm{S}(\mathrm{P})_{\mathrm{jk}(\mathrm{i})}$ if the response between sites is not homogeneous. When the factor $\mathrm{S}(\mathrm{P})$ was not significant its sum of squares and that of residuals were joined and the analysis of the main $\mathrm{T} \times \mathrm{P}$ factors was carried out again. This pooling was only carried out when the probability of accepting the null hypothesis when it is true was high $(P>0.20)$ (Underwood 1997). If there was a significant interaction $(\mathrm{T} \times \mathrm{P})$, further analyses were carried out as independent comparisons of protection level at each time by means of multiple comparisons using the Student-NeumanKeuls procedure.

Before the analyses were performed, the homogeneity of variances (by means of the Cochran test (Zar 1984)), the absence of correlation between means and the standard deviations and data normality were tested. When these assumptions were not fulfilled, data were $\log \left(\mathrm{x}^{\prime}=\log (\mathrm{x}+1)\right.$ or square root $\left(x^{\prime}=\sqrt{ } x\right)$ transformed. If these assumptions were still not achieved even with these transformation, the raw data were analysed, taking care to increase the significance level from $P<0.05$ to $P<0.01$ to avoid the risk of type I error (Underwood 1997).

Within each protection level or within each site, if this last factor was significant, a linear regression analysis was performed between the mean value of each indicator and protection time in order to determine the sign of the variations indicated by the ANOVA.

\section{The effect of habitat and protection}

We used two approaches to determine the effects of the habitat variables on the indicators and whether it is possible to confuse them with the $\mathrm{T} \times \mathrm{P}$ interaction: we compared all the habitat variables at the protection level and site level through nested ANOVA; and we performed a forward multiple regression analysis between the habitat variables recorded in each transect with the indicators as response variables. In both cases the percentage cover data were square root transformed and Pearson correlation analysis was used to test the colinearity of all independent variables. The sum of all the blocks (B) was positively correlated with LB $(\mathrm{R}>0.6 ; \mathrm{P}<0.000)$ and rugosity, and negatively correlated with $\mathrm{RH}$. This indicates that in most situations where there were no blocks, $\mathrm{RH}$ was dominant and vice versa. RH correlated negatively with rugosity $(\mathrm{R}=-0.59 ; \mathrm{P}<0.000)$. Thus, total blocks and $\mathrm{RH}$ were not included in further analyses. Posidonia and sand covers were minor and occurred with practically all substrata types. The maximum and minimum depths were averaged in each transect to test the effect of the mean depth.

The determination coefficient $\left(R^{2}\right)$ for each resulting equation was tested by an $F$ test. When the variance explained by the equation was significant $(P<0.05)$ and greater than the highest sampling precision obtained for the response variable at any site and time, we performed the same ANOVA analysis that was applied to indicators but using the residual values from the multiple regression analysis as dependent variables. Therefore, we compared the results showing the effects of protection level and time on the indicator with the results when the habitat component was not considered (Chapman and Kramer 1999, García-Charton et al. 2004). The percentage of the standard error with respect to the mean value ((se/mean)-100) for each site and sampling time was used as a measure of the sampling precision for the synthetic indicators (Samoylis and Carlos 1992).

\section{The carrying capacity in the three MPAs}

As there are no anthropogenic disturbances in the no-take areas, the system is expected to reach its full carrying capacity; therefore, in addition to the linear approach performed through ANOVA, we tested other non-linear functions in the no-take areas only. The mean total biomass $(\mathrm{Bt})$ was used as the dependent variable because it includes the increases in species number as well as fish abundance and size. Furthermore, the use of Bt is justified from a fisheries perspective as the MPAs included in this study were created to enhance fishing, and fisheries management has traditionally been based on biomass reference points (Caddy and Mahon, 1995).

Different functions were fitted for protection time and mean $\mathrm{Bt}$, using the non-linear least-squares Levenberg-Marquardt algorithm. The proportion of variance explained by each model $\left(R^{2}\right)$ was analysed with an $F$ test corrected for degrees of freedom (adjusted $R^{2}$ ). The models studied were:

A constant linear increase in biomass over time $(\mathrm{T})$, where $\mathrm{Bt}=\mathrm{a}+\mathrm{b} \cdot \mathrm{T}$. 
TABLE 1. - Freus MPA. Summary of ANOVA results for the factors P, protection, T, time, S, site, and their interactions on five indicators of the target fish assemblage. Bt, total biomass; St, number of species; $S_{20}$, number of species for fish greater than $20 \mathrm{~cm}$; Dt, total density of fish; $\mathrm{D}_{20}$, density of fish greater than $20 \mathrm{~cm}$. Precision=maximum, average and minimum ((se/mean)*100) for any site within a given protection level and time. Underlined $=\log _{10}(\mathrm{x}+1)$ transformed. Underlined ${ }^{*}=\log _{10}\left((\mathrm{X})^{0.5}+1\right)$ transformed. The temporal trend of these indicators is shown as: $\uparrow$, increase; $\downarrow$, decrease; $\leftrightarrow$, stability or once-off shifts with no defined trend. The significance of these trends is shown by a $t$ test on the slope of a linear fitting $(* P<0.05 ; * * P<0.025 ; * * * P<0.01$; ns, not significant). The equation resulting from the multiple regression analysis between the indicator and habitat variables is shown in the penultimate column (see Table 4 for abbreviations of variables). When the variance explained by these models $\left(R^{2}\right)$ is greater than the maximum sampling precision, the last column shows the ANOVA results performed on residuals of the multiple regression.

\begin{tabular}{|c|c|c|c|c|c|}
\hline $\begin{array}{l}\text { Indicator and } \\
\text { precision }(\%)\end{array}$ & $\begin{array}{l}\text { Source } \\
\text { of variation }\end{array}$ & $\begin{array}{l}F \text { test, degrees of } \\
\text { freedom and significance }\end{array}$ & Trend & $\begin{array}{l}\text { Multiple regression } \\
\text { equation }\end{array}$ & $\begin{array}{l}\text { ANOVA } \\
\text { for residuals }\end{array}$ \\
\hline $\begin{array}{l}\mathrm{Bt} \\
(10.4-18.7-31.5)\end{array}$ & $\begin{array}{l}\mathrm{T} \\
\mathrm{P} \\
\mathrm{T} \times \mathrm{P} \\
\mathrm{S}(\mathrm{P}) \\
\mathrm{T} \times \mathrm{S}(\mathrm{P})\end{array}$ & $\begin{array}{l}F_{7,21}=9.46 * * * \\
F_{2,3}=4.49 \mathrm{~ns} \\
F_{14,21}=4.05 * * * \\
F_{3,21}=14.78 * * * \\
F_{21,816}=1.01 \mathrm{~ns}\end{array}$ & $\begin{array}{l}\text { R1: } \uparrow \mathrm{ns} \\
\text { R2: }{ }^{*} \\
\text { PR1: } \leftrightarrow \\
\text { PR2: } \uparrow * * * \\
\text { NR1: } \leftrightarrow \\
\text { NR2: } \leftrightarrow\end{array}$ & $\begin{array}{c}\text { 1078.2+100.6(MD)+ } \\
+325.8(\mathrm{SLO})-11.4(\mathrm{POSI}) \\
R^{2}=0.02 * * *\end{array}$ & None \\
\hline $\begin{array}{l}\mathrm{St} \\
(5.3-7.7-13.4)\end{array}$ & $\begin{array}{l}\mathrm{T} \\
\mathrm{P} \\
\mathrm{T} \times \mathrm{P} \\
\mathrm{S}(\mathrm{P}) \\
\mathrm{T} \times \mathrm{S}(\mathrm{P})\end{array}$ & $\begin{array}{l}F_{7,21}=22.88 * * * \\
F_{2,3}=2.98 ; \mathrm{ns} \\
F_{14,21}=7.56 * * * \\
F_{3,21}=7.56 * * * \\
F_{21,816}=1.09 \mathrm{~ns}\end{array}$ & $\begin{array}{l}\text { R1: } \uparrow * * * \\
\text { R2: } \uparrow * * * \\
\text { PR1: } \leftrightarrow \\
\text { PR2: } \uparrow * * * \\
\text { NR1: } \leftrightarrow \\
\text { NR2: } \leftrightarrow\end{array}$ & $\begin{array}{c}2.3+0.13(\mathrm{RUG})+ \\
+0.23(\mathrm{SLO})-0.02(\mathrm{SAND}) \\
R^{2}=0.05^{* * *}\end{array}$ & None \\
\hline $\begin{array}{l}\text { Dt } \\
(6.9-16.2-41.9)\end{array}$ & $\begin{array}{l}\mathrm{T} \\
\mathrm{P} \\
\mathrm{T} \times \mathrm{P} \\
\mathrm{S}(\mathrm{P}) \\
\mathrm{T} \times \mathrm{S}(\mathrm{P})\end{array}$ & $\begin{array}{l}F_{7,21}=1.49 \mathrm{~ns} \\
F_{2,3}=0.73 \mathrm{~ns} \\
F_{14,21}=1.42 \mathrm{~ns} \\
F_{3,21}=12.51 \text { *** } \\
F_{21,816}=1.06 \mathrm{~ns}\end{array}$ & $\begin{array}{l}\mathrm{R} 1: \uparrow \mathrm{ns} \\
\mathrm{R} 2: \uparrow \mathrm{ns} \\
\mathrm{PR} 1: \overleftrightarrow{\uparrow} \\
\text { PR2: }{ }^{2} * * \\
\text { NR1: } \\
\text { NR2: } \downarrow * * *\end{array}$ & $\begin{array}{c}23.0-0.77(\mathrm{MD})+3.0(\mathrm{SLO}) \\
R^{2}=0.02 * * *\end{array}$ & None \\
\hline $\begin{array}{l}\mathrm{S}_{20} \\
(7.3-18.9-42.3)\end{array}$ & $\begin{array}{l}\mathrm{T} \\
\mathrm{P} \\
\mathrm{T} \times \mathrm{P} \\
\mathrm{S}(\mathrm{P}) \\
\mathrm{T} \times \mathrm{S}(\mathrm{P})\end{array}$ & $\begin{array}{l}F_{7,21}=21.92 * * * \\
F_{2,3}=13.17 * \\
F_{14,21}=4.98 * * * \\
F_{3,21}=7.51 * * * \\
F_{21,816}=1.56 \mathrm{~ns}\end{array}$ & $\begin{array}{l}\text { R1: } \uparrow * \\
\text { R2: } \uparrow * * * \\
\text { PR1: } \leftrightarrow \\
\text { PR2: } \uparrow * \\
\text { NR1: } \leftrightarrow \\
\text { NR2: } \leftrightarrow\end{array}$ & $\begin{array}{c}0.48-0.08(\mathrm{MD})+0.15(\mathrm{SLO})- \\
-0.02(\mathrm{SAND})+0.14(\mathrm{RUG}) \\
R^{2}=0.04^{* * *}\end{array}$ & None \\
\hline $\begin{array}{l}\mathrm{D}_{20} \\
(13.2-26.0-49.2)\end{array}$ & $\begin{array}{l}\mathrm{T} \\
\mathrm{P} \\
\mathrm{T} \times \mathrm{P} \\
\mathrm{S}(\mathrm{P}) \\
\mathrm{T} \times \mathrm{S}(\mathrm{P})\end{array}$ & $\begin{array}{l}F_{7,21}=13.23 * * * \\
F_{2,3}=7.56 \mathrm{~ns} \\
F_{14,21}=4.49 * * * \\
F_{3,21}=8.23 * * * \\
F_{21,816}=1.26 \mathrm{~ns}\end{array}$ & 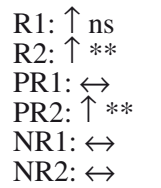 & $\begin{array}{c}1.6-0.21(\mathrm{MD})+0.4(\mathrm{SLO}) \\
R^{2}=0.013^{* * *}\end{array}$ & None \\
\hline
\end{tabular}

A sustained increase over time or exponential increase, where $\mathrm{Bt}=\mathrm{a} \cdot \mathrm{e}^{(\mathrm{r} \cdot \mathrm{T})}$, where $r=$ the intrinsic rate of increase and $\mathrm{e}=$ Euler.

Initial fast growth that later slows down approaching a theoretical maximum Bt. This is the Von Bertalanffy model: $\mathrm{Bt}=\mathrm{K} \cdot\left[1-\mathrm{e}^{\left(-\mathrm{r}\left(\mathrm{T}+\mathrm{t}_{0}\right)\right.}\right]$, where $\mathrm{K}=$ maximum theoretical $\mathrm{Bt}$ and $\mathrm{t}_{0}=$ theoretical time when the biomass of the system would be zero.

The best-fit logistic curve (Kaufman 1981), sigmoid in shape and symmetrical with respect to the inflexion point, approaching an asymptote (K) over time. It incorporates $\mathrm{t}_{0}$ with respect to the traditional logistic curve: $\mathrm{Bt}=\mathrm{K} \cdot\left[1+\mathrm{e}^{-\mathrm{r}\left(\mathrm{T}+\mathrm{t}_{0}\right)}\right]^{-1}$.

The Gompertz curve, which is similar to the logistic curve but is non-symmetrical with respect to the inflexion point and approaches the asymptote $(\mathrm{K})$ more gradually: $\mathrm{Bt}=\mathrm{K} \cdot \mathrm{e}\left[-\mathrm{e}^{\left(-\mathrm{a}\left(\mathrm{T}+\mathrm{t}_{0}\right)\right.}\right]$.

The $\mathrm{K} \pm$ se parameter from the asymptotic curves was interpreted to be the carrying capacity of the system. These values were compared by a two-tailed $t$ test with mean $\mathrm{B} \pm \mathrm{se}$ values obtained in a given protection time.

\section{RESULTS}

Nineteen species belonging to eight families were censused during the entire monitoring period. Eighteen species were censused at Freus, 11 at Palma and 16 at Menorca. Ten of these species were macrocarnivorous fish with high trophic levels (TL, 4.0 \pm 0.1 ): the Congridae Conger conger; the Serranidae Mycteroperca rubra, Epinephelus caninus, E. costae and E. margina-

TABLE 2. - Freus MPA. Post hoc analysis results from the StudentNewman-Keuls test for a significance level of $P=0.05$.

\begin{tabular}{lcccc}
\hline $\begin{array}{l}\text { Sampling } \\
\text { time }\end{array}$ & Bt & St & S20 & Indicator \\
\hline Time 1 & $\mathrm{R}=\mathrm{PR}=\mathrm{NR}$ & $(\mathrm{PR}=\mathrm{NR})>\mathrm{R}$ & $\mathrm{R}=\mathrm{PR}=\mathrm{NR}$ & $\mathrm{R}=\mathrm{PR}=\mathrm{NR}$ \\
Time 2 & $\mathrm{R}=\mathrm{PR}=\mathrm{NR}$ & $(\mathrm{PR}=\mathrm{NR})>\mathrm{R}$ & $\mathrm{R}=\mathrm{PR}=\mathrm{NR}$ & $\mathrm{R}=\mathrm{PR}=\mathrm{NR}$ \\
Time 3 & $(\mathrm{R}=\mathrm{PR})>\mathrm{NR}$ & $\mathrm{R}=\mathrm{PR}=\mathrm{NR}$ & $\mathrm{R}>(\mathrm{PR}=\mathrm{NR})$ & $(\mathrm{R}=\mathrm{PR})>\mathrm{NR}$ \\
Time 4 & $\mathrm{R}>(\mathrm{PR}=\mathrm{NR})$ & $\mathrm{R}>(\mathrm{PR}=\mathrm{NR})$ & $\mathrm{R}>\mathrm{PR}>\mathrm{NR}$ & $\mathrm{R}>(\mathrm{PR}=\mathrm{NR})$ \\
Time 5 & $\mathrm{R}>(\mathrm{PR}=\mathrm{NR})$ & $\mathrm{R}>\mathrm{PR}>\mathrm{NR}$ & $\mathrm{R}>\mathrm{PR}>\mathrm{NR}$ & $\mathrm{R}>(\mathrm{PR}=\mathrm{NR})$ \\
Time 6 & $\mathrm{R}>(\mathrm{PR}=\mathrm{NR})$ & $(\mathrm{R}=\mathrm{PR})>\mathrm{NR}$ & $\mathrm{R}>\mathrm{PR}>\mathrm{NR}$ & $\mathrm{R}>\mathrm{PR}>\mathrm{NR}$ \\
Time 7 & $\mathrm{R}>(\mathrm{PR}=\mathrm{NR})$ & $\mathrm{R}>(\mathrm{PR}=\mathrm{NR})$ & $\mathrm{R}>(\mathrm{PR}=\mathrm{NR})$ & $\mathrm{R}>(\mathrm{PR}=\mathrm{NR})$ \\
Time 8 & $(\mathrm{R}=\mathrm{PR})>\mathrm{NR}$ & $(\mathrm{R}=\mathrm{PR})>\mathrm{NR}$ & $\mathrm{R}>\mathrm{PR}>\mathrm{NR}$ & $(\mathrm{R}=\mathrm{PR})>\mathrm{NR}$ \\
\hline
\end{tabular}


No Take Area

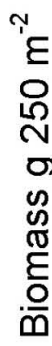

Partial Reserve
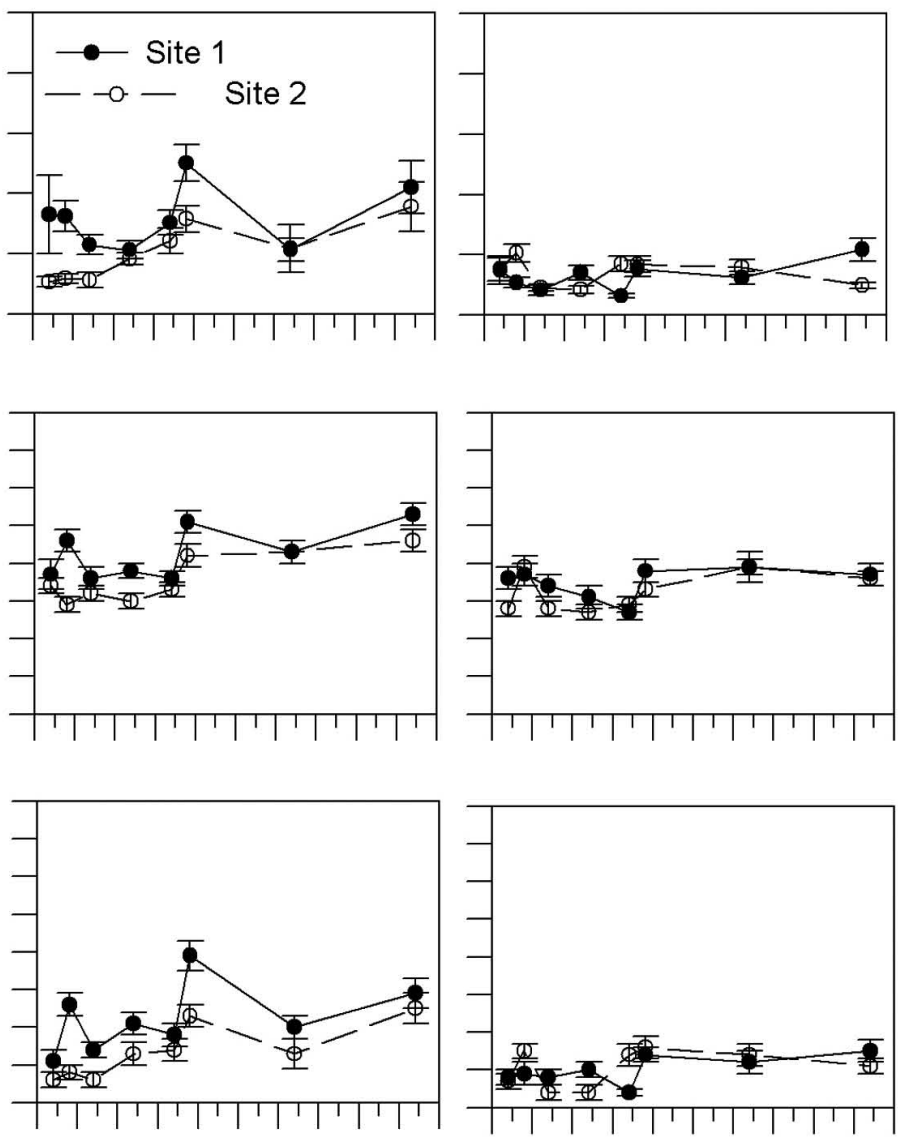
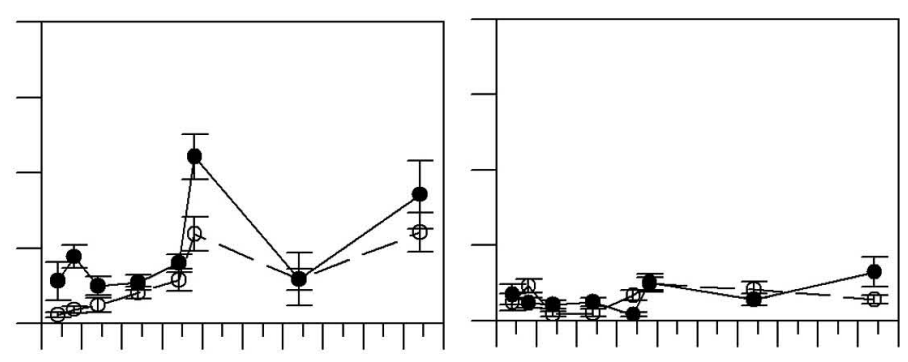

'E
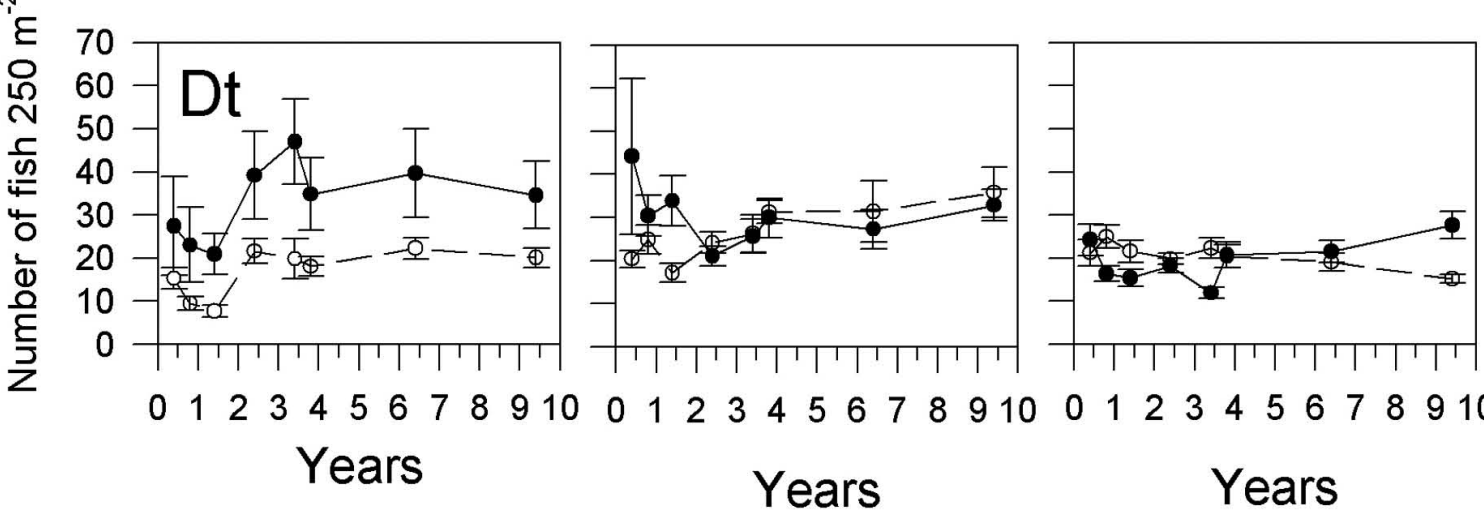

Years

FIG. 2. - Patterns of change over time for five indicators of the target fish assemblage at different protection levels at Freus of the Ibiza and Formentera Marine Reserve. Bt, total biomass; St, number of species; $S_{20}$, number of species of fish greater than $20 \mathrm{~cm} ; D_{20}$, density of fish greater than $20 \mathrm{~cm}$; Dt, total density of fish. 
TABLE 3. - ANOVA results for the TxP interaction for the biomass of different target fish families in the three MPAs. The mean values for biomass ( $\mathrm{g} \pm \mathrm{se})$ within each protection level for the first $(2000)$ and the last $(2009,2008,2007)$ sampling times are shown; Po, pooling of site plus error term.

\begin{tabular}{|c|c|c|c|c|c|c|c|c|}
\hline \multirow{2}{*}{$\begin{array}{l}\text { TIME } \\
\text { Protection }\end{array}$} & \multirow{2}{*}{$\begin{array}{c}\text { First } \\
\mathrm{R}\end{array}$} & \multirow{2}{*}{$\begin{array}{c}\text { Last } \\
\mathrm{R}\end{array}$} & \multirow{2}{*}{$\begin{array}{c}\text { First } \\
\text { PR }\end{array}$} & \multirow{2}{*}{$\begin{array}{l}\text { Last } \\
\text { PR }\end{array}$} & \multirow{2}{*}{$\begin{array}{l}\text { First } \\
\text { NR }\end{array}$} & \multirow{2}{*}{$\begin{array}{l}\text { Last } \\
\text { NR }\end{array}$} & \multicolumn{2}{|c|}{ ANOVA Results (TxP) } \\
\hline & & & & & & & $F$ & $P$ \\
\hline \multicolumn{7}{|l|}{ Freus MPA } & \multicolumn{2}{|l|}{$F_{(1421)}$} \\
\hline Sparidae & $1690 \pm 457$ & $2250 \pm 406$ & $1898 \pm 634$ & $2712 \pm 476$ & $1073 \pm 200$ & $1239 \pm 198$ & 2.92 & 0.013 \\
\hline Serranidae & $85 \pm 34$ & $915 \pm 281$ & $136 \pm 70$ & $411 \pm 112$ & $253 \pm 151$ & $96 \pm 38$ & 1.69 & 0.135 \\
\hline Labridae & $49 \pm 43$ & $1197 \pm 151$ & $82 \pm 32$ & $299 \pm 58$ & $48 \pm 21$ & $93 \pm 24$ & 11.35 & 0.000 \\
\hline Sciaenidae & $1 \pm 1$ & $391 \pm 174$ & $0 \pm 0$ & $396 \pm 136$ & $44 \pm 26$ & $130 \pm 47$ & 1.28 & 0.294 \\
\hline Eelfish & $118 \pm 107$ & $326 \pm 123$ & $72 \pm 59$ & $33 \pm 19$ & $70 \pm 59$ & $9 \pm 9$ & 1.71 & 0.129 \\
\hline Scorpaenidae & $37 \pm 16$ & $164 \pm 69$ & $3 \pm 3$ & $36 \pm 15$ & $26 \pm 21$ & $9 \pm 5$ & 3.26 & 0.007 \\
\hline \multicolumn{7}{|l|}{ Palma MPA } & \multicolumn{2}{|l|}{$F_{(10,306) P_{o}}$} \\
\hline Sparidae & $999 \pm 205$ & $1952 \pm 368$ & $790 \pm 131$ & $1509 \pm 589$ & $633 \pm 70$ & $1246 \pm 511$ & 1.43 & 0.167 \\
\hline Serranidae & $3 \pm 3$ & $49 \pm 49$ & $96 \pm 51$ & $49 \pm 49$ & $82 \pm 59$ & - & 0.80 & 0.632 \\
\hline Labridae & $3 \pm 3$ & $474 \pm 99$ & $12 \pm 6$ & $98 \pm 54$ & $43 \pm 16$ & $94 \pm 39$ & 6.53 & 0.000 \\
\hline \multicolumn{7}{|c|}{ North Menorca MPA } & \multicolumn{2}{|l|}{$F_{(14,21)}$} \\
\hline Sparidae & $503 \pm 119$ & $1957 \pm 263$ & $946 \pm 365$ & $1933 \pm 276$ & $487 \pm 159$ & $1299 \pm 547$ & 0.89 & 0.577 \\
\hline Serranidae & $191 \pm 87$ & $1264 \pm 318$ & $285 \pm 115$ & $747 \pm 153$ & $497 \pm 148$ & $485 \pm 117$ & 1.91 & 0.087 \\
\hline Labridae & $72 \pm 37$ & $136 \pm 42$ & $27 \pm 9$ & $69 \pm 20$ & $29 \pm 16$ & $79 \pm 21$ & 3.70 & 0.004 \\
\hline Sciaenidae & - & $125 \pm 60$ & - & $60 \pm 31$ & - & $12 \pm 6$ & 0.95 & 0.531 \\
\hline Eelfish & $22 \pm 22$ & - & $57 \pm 57$ & $115 \pm 61$ & $174 \pm 174$ & $115 \pm 60$ & 1.39 & 0.242 \\
\hline Scorpaenidae & $22 \pm 12$ & $4 \pm 4$ & - & - & $15 \pm 15$ & - & 0.54 & 0.882 \\
\hline
\end{tabular}

tus; the Muraenidae Muraena helena and Gymnothorax unicolor; the Scorpaenidae Scorpaena porcus and S. scrofa; and the Gadidae Phycis phycis. Invertebrate feeders were the next trophic level (TL: $3.4 \pm 0.1$ ), with five species which can occasionally also feed on small fish, such as the Sparidae Diplodus vulgaris and Sparus aurata, the Labridae Labrus merula and L. viridis, and the Sciaenidae Sciaena umbra. Finally, the lowest trophic level, the omnivorous fish (TL: $3.1 \pm 0.1$ ), was the least represented, with only four species: the Sparidae D. puntazzo, D. sargus, D. cervinus and Spondyliosoma cantharus.

\section{Freus MPA in Ibiza and Formentera}

The indicators Bt, St, $\mathrm{S}_{20}$ and $\mathrm{D}_{20}$ showed different temporal trends within the different protection levels, which is indicated by the significant $\mathrm{T} \times \mathrm{P}$ interaction (Table 1). The post hoc tests showed that no indicators had higher values in the R or PR areas than in the non-protected area during the first study year, a pattern which shifted to the inverse as protection time increased (Table 2).

The effect of site was also significant and produced different recovery rates both in the no-take area and in the partial reserve. Within the no-take area, Bt doubled $(\times 2.3)$ between the first and the last study year at R1 while it tripled (x3.4) at R2. Fish biomass also diversified in the no-take area, doubling the value of $\mathrm{St}$ at both sites (Fig. 2). The values of $\mathrm{S}_{20}$ were nearly four times greater at both R1 $(\times 3.7)$ and R2 $(\times 3.9)$, while $\mathrm{D}_{20}$ increased 4.3 times at $\mathrm{R} 1$ and 7.1 times at R2 (Fig. 2). These were not occasional increases but rather corresponded to increasing patterns which tended to reach an asymptote between the fourth and fifth year of total protection, which was why their linear fitting was not always significant (Table 1).
The five most frequent fish families within the notake area showed increasing trends over time and are the reason for the above mentioned increasing trends, though only Sparidae, Labridae and Scorpaenidae showed a significant $\mathrm{T} \times \mathrm{P}$ interaction (Table 3 ).

In the partial reserve, PR1 showed cyclic temporal variations without a clear pattern for any indicator (Fig. 2). In PR2 there was a significant linear increase in $\mathrm{Bt}\left(R^{2}=0.72, P=0.008\right)$ resulting from an overall increase in all indicators (Table 1 and Fig. 2). The control sites did not show either growing trends or significant differences over time for any indicator (Table 1).

Habitat variables played a negligible role in the recovery of resources given that no combination of variables could explain more than $5 \%$ of the variation: a percentage which is much lower than the sampling error estimated at any site at all sampling times (Table 1). Habitat differences occurred only at site level and not between protection levels (Table 4).

\section{Palma Bay MPA}

The protection by time interaction was only significant for $\mathrm{St}$ and $\mathrm{S}_{20}$ (Table 5). Post hoc tests showed that species richness was lower in the R than in the PR and the control area in the first sampling. During the fourth year St was already higher in the R and PR than in the control areas, while for the last sampling only $\mathrm{R}$ showed a higher mean St than the control area (Fig. 3 and Table 6). The multiple regression analysis showed that rugosity and slope accounted for up to $18 \%$ of the variation in St (Table 5). When the effect of these covariables was excluded, protection time continued to be highly significant $(P<0.01)$ although the $\mathrm{T} \times \mathrm{P}$ interaction was not significant (Table 5). In the case of $\mathrm{S}_{20}$, the $\mathrm{T} \times \mathrm{P}$ interaction, with $P=0.03$, was not strictly 
significant because of the heterogeneity of variances (Cochran test, $P<0.001$ ). Nevertheless, when the effect of habitat, which can account for up to $16 \%$ of the variation of this indicator, was excluded, the residuals of $\mathrm{S}_{20}$ showed a greater interaction $(P=0.018)$ (Table 5).

The rest of the indicators showed significant temporal differences in both protected and unprotected areas. Despite these variations, some of which only occurred at a specific time, all indicators except Dt showed significant increasing trends within $\mathrm{R}$ and $\mathrm{S}_{20}$ and $\mathrm{D}_{20}$ also in PR. The site effect was not significant for these indicators and the linear fitting for all the mean values from $\mathrm{R}$ was accurate and significant for Bt $\left(R^{2}=0.631\right.$, $P=0.002)$, St $\left(R^{2}=0.762, P=0.0002\right), \mathrm{S}_{20} \quad\left(R^{2=0.69}\right.$, $P=0.0008)$ and $\mathrm{D}_{20}\left(R^{2}=0.52, P=0.008\right)$. Labridae again played an important role in the increases of $\mathrm{Bt}$, showing significant greater mean biomasses in the last sampling time (Table 3).

In the partially protected area a less accurate increasing pattern was found for the indicators that account for large fish: $\mathrm{S}_{20}, R^{2}=0.44, P=0.019$ and $\mathrm{D}_{20} R^{2}=0.42$, $P=0.023$. The control sites showed some increase in a given time but with no defined pattern for any indicator (Fig. 3 and Table 5)

\section{North Menorca MPA}

All indicators showed significant changes over time at all protection levels, and thus the $\mathrm{T} \times \mathrm{P}$ interaction was not significant in any case (Table 7).

The local effect at site level was very large for most indicators. Within the no-take area, $\mathrm{Bt}, \mathrm{Dt}, \mathrm{S}_{20}$ and $\mathrm{D}_{20}$ showed growing trends but they were only significant at R1 (Table 7 and Fig. 4). Bt was under $1000 \mathrm{~g} 250$ $\mathrm{m}^{-2}$ on the first sampling date, while it had increased by a factor of $\mathrm{x} 4$ at both R1 (916.6 vs $4220.2 \mathrm{~g}$ ) and R2 (705.1 vs $2754.4 \mathrm{~g}$ ) after 7 years (Fig. 4). The density of large fish $(>20 \mathrm{~cm})$ was very low at the beginning of the study; however, this was the indicator that increased most between 2000 and 2007, by a factor of $\times 4.8$ at R1 and by $\times 13$ at R2 (Fig. 4). The sharp drop in all indicators in 2005 meant that the later increase and high final values were not enough to make the linear fittings significant at Site 2 (Table 7).

Growing trends were also observed within the partially protected reserve but they were only significant in PR2 (Table 7). Bt, Dt and $\mathrm{D}_{20}$ have increased at this site by $3.8,1.7$ and 5.9, respectively, since 2000. Similar but not significant trends were observed for $\mathrm{Bt}, \mathrm{S}_{20}$ and $D_{20}$ at PR1, which showed maximum values in 2003 that later decreased (Fig. 4). Serranidae and Labridae were the families involved in a better response to protection (Table 3).

At the control sites, Bt decreased at NR1 within this period while it increased by 3.3 at NR2 (886.5 g vs $2918.8 \mathrm{~g}$ ) with a high spatial variation at transect level (Fig. 4).

The influence of habitat variables on these results was negligible given that they did not explain more 

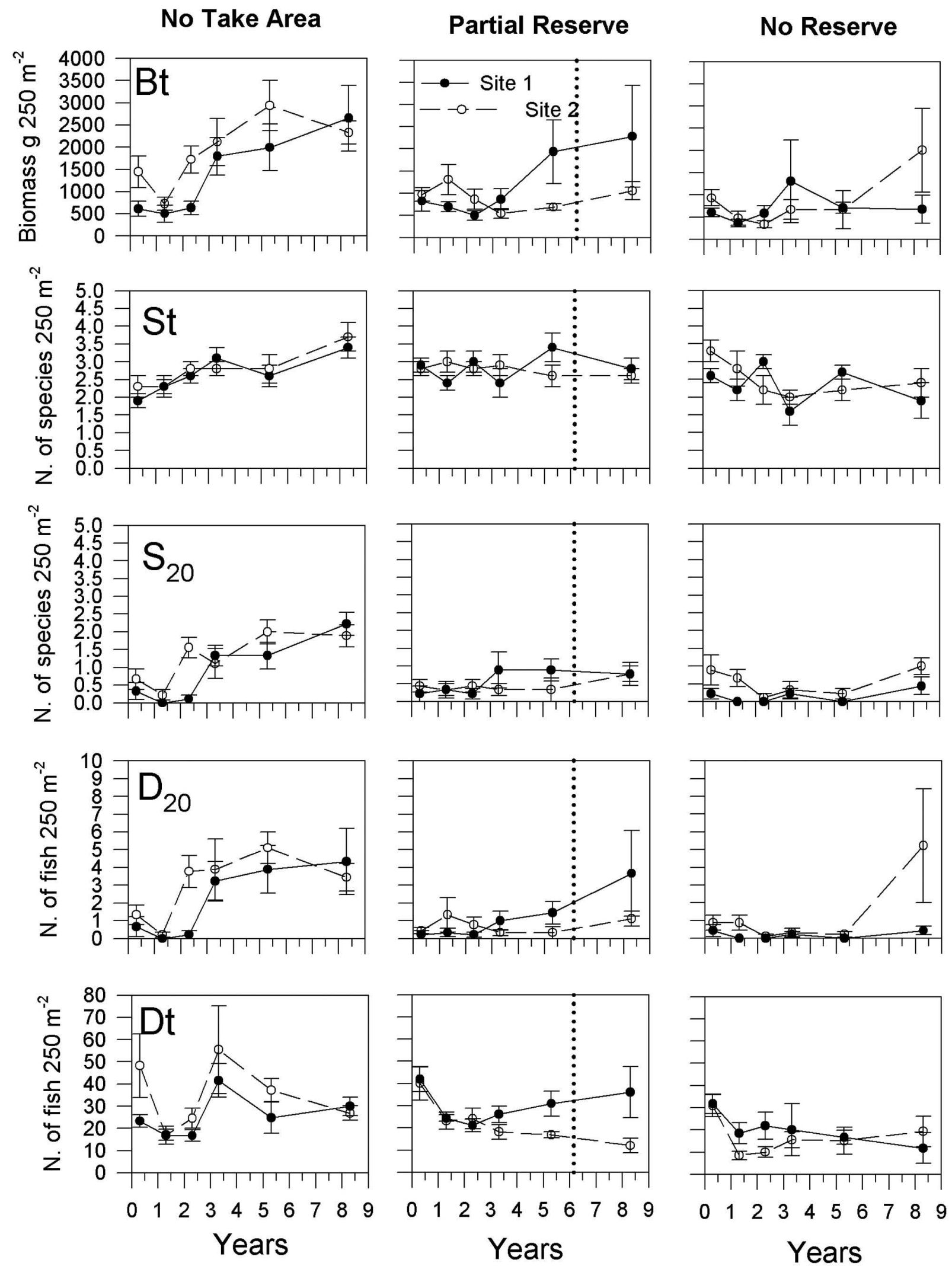

FIG. 3. - Patterns of change over time for five indicators of the target fish assemblage at different protection levels of the Palma Bay Marine Reserve. Bt, total biomass; St, number of species; $S_{20}$, number of species of fish greater than $20 \mathrm{~cm} ; \mathrm{D}_{20}$, density of fish greater than $20 \mathrm{~cm}$; Dt, total density of fish. The dashed line in the partial reserve graphs indicates the time when site 1 was included in the no-take area. 

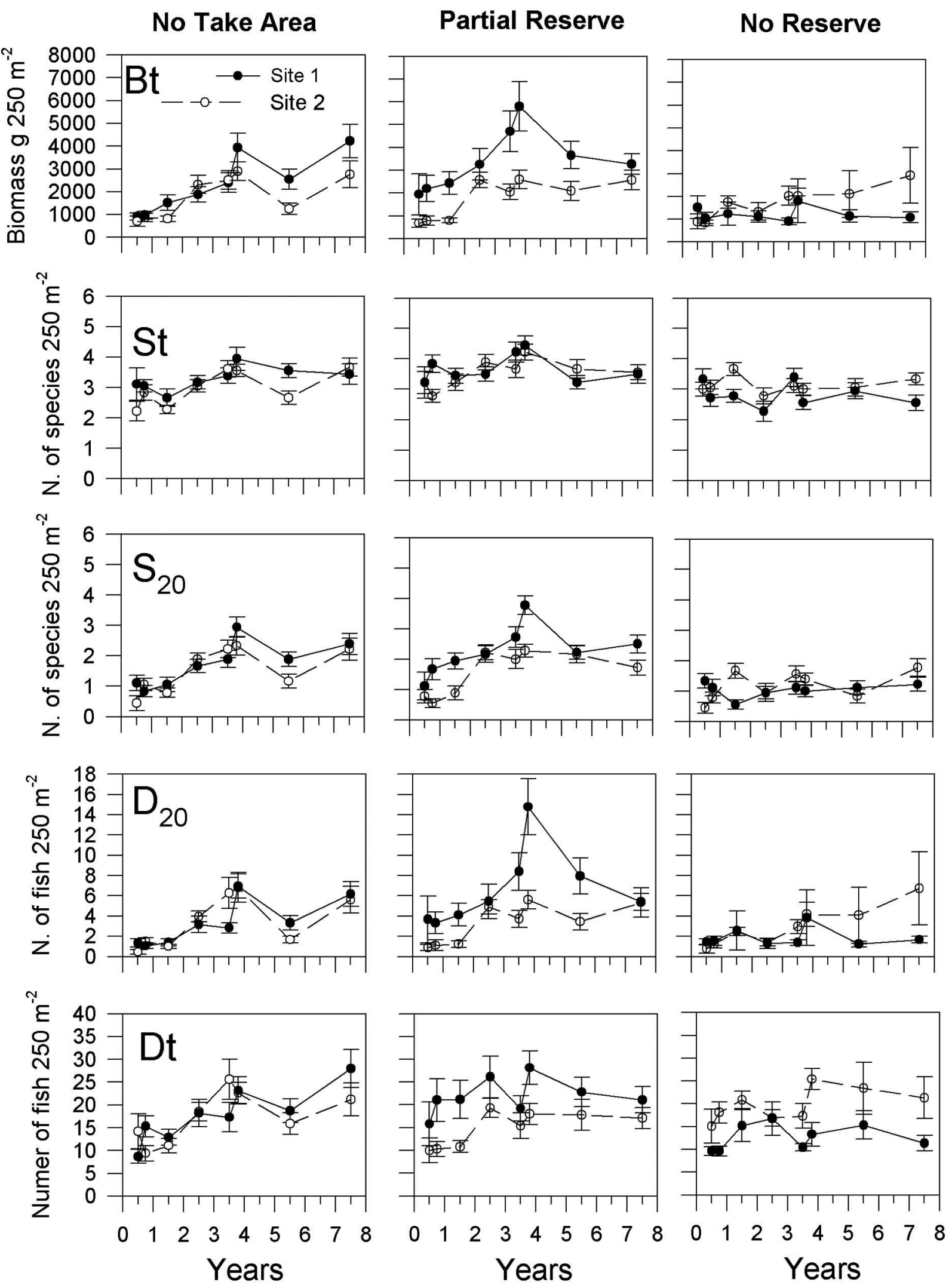

FIG. 4. - Patterns of change over time for five indicators of the target fish assemblage at different protection levels of the North Menorca Marine Reserve. Bt, total biomass; St, number of species; $S_{20}$, number of species of fish greater than $20 \mathrm{~cm}$; $D_{20}$, density of fish greater than $20 \mathrm{~cm}$; Dt, total density of fish. 
TABLE 5. - Palma MPA. See Table 1 for the explanation of headers.

\begin{tabular}{|c|c|c|c|c|c|}
\hline $\begin{array}{l}\text { Indicator and } \\
\text { precision }(\%)\end{array}$ & $\begin{array}{l}\text { Source of } \\
\text { variation }\end{array}$ & $\begin{array}{l}F \text { test, degrees of freedom } \\
\text { and significance }\end{array}$ & Trend & $\begin{array}{l}\text { Multiple } \\
\text { regression equation }\end{array}$ & $\begin{array}{l}\text { ANOVA } \\
\text { for residuals }\end{array}$ \\
\hline $\begin{array}{l}\mathrm{Bt} \\
(10.1-28.0-64.6)\end{array}$ & $\begin{array}{l}\mathrm{T} \\
\mathrm{P} \\
\mathrm{T} \times \mathrm{P} \\
\mathrm{S}(\mathrm{P}) \\
\mathrm{T} \times \mathrm{S}(\mathrm{P})\end{array}$ & $\begin{array}{l}F_{5,15}=5.27 * * * \\
F_{2,3}=6.17 \mathrm{~ns} \\
F_{10,15}=1.24 \mathrm{~ns} \\
F_{3,15}=1.57 \mathrm{~ns} \\
F_{15,288}=1.29 \mathrm{~ns}\end{array}$ & $\begin{array}{l}\mathrm{R}: \uparrow * * * \\
\mathrm{PR}: \leftrightarrow \\
\mathrm{NR}: \leftrightarrow\end{array}$ & $\begin{array}{c}-621.1+18.6(\mathrm{MB})+ \\
+310.8(\mathrm{RUG})+11.1(\mathrm{MD}) \\
R^{2} \mathrm{adj}=0.13^{* * *}\end{array}$ & $\begin{array}{l}7.2 * * * \\
5.04 \mathrm{~ns} \\
1.68 \mathrm{~ns} \\
1.81 \mathrm{~ns} \\
1.1 \mathrm{~ns}\end{array}$ \\
\hline $\begin{array}{l}\text { St } \\
(7.1-11.8-27.1)\end{array}$ & $\begin{array}{l}\mathrm{T} \\
\mathrm{P} \\
\mathrm{T} \times \mathrm{P} \\
\mathrm{S}(\mathrm{P}) \\
\mathrm{T} \times \mathrm{S}(\mathrm{P})\end{array}$ & $\begin{array}{l}F_{5,15}=0.78 \mathrm{~ns} \\
F_{2,3}=8.89 \mathrm{~ns} \\
F_{10,15}=3.07 * * \\
F_{3,15}=0.45 \mathrm{~ns} \\
F_{15,288}=1.27 \mathrm{~ns}\end{array}$ & $\begin{array}{l}\mathrm{R}: \uparrow * * * \\
\mathrm{PR}: \overleftrightarrow{\mathrm{NR}} \overleftrightarrow{\downarrow}_{\mathrm{ns}}\end{array}$ & $\begin{array}{c}1.8+0.44(\mathrm{RUG})+0.18(\mathrm{SLO}) \\
R^{2} \mathrm{adj}=0.18^{* * *}\end{array}$ & \\
\hline Pooling S+Error term & $\begin{array}{l}\mathrm{T} \\
\mathrm{P} \\
\mathrm{T} \times \mathrm{P}\end{array}$ & $\begin{array}{l}F_{5,15}=0.99 \mathrm{~ns} \\
F_{2,3}=5.08 * * * \\
F_{10,15}=3.87 * * *\end{array}$ & & & $\begin{array}{l}7.6 * * * \\
9.7 * * * \\
1.8 \mathrm{~ns}\end{array}$ \\
\hline $\begin{array}{l}\mathrm{Dt} \\
(6.1-22.4-58.3)\end{array}$ & $\begin{array}{l}\mathrm{T} \\
\mathrm{P} \\
\mathrm{T} \times \mathrm{P} \\
\mathrm{S}(\mathrm{P}) \\
\mathrm{T} \times \mathrm{S}(\mathrm{P})\end{array}$ & $\begin{array}{c}F_{5,15}=6.41 * * * \\
F_{2,3}=2.76 \mathrm{~ns} \\
F_{10,15}=2.09 \mathrm{~ns} \\
F_{3,15}=3.79 * \\
F_{15,288}=0.97 \mathrm{~ns} \\
\text { NR2: } \leftrightarrow\end{array}$ & $\begin{array}{l}\text { R1: } \uparrow \mathrm{ns} \\
\text { R2: ↔ } \\
\text { PR1: } \\
\text { PR2: }{ }^{*} * \\
\text { NR1: } \downarrow *\end{array}$ & $\begin{array}{c}12.5+4.23 \text { (RUG) } \\
R^{2} \text { adj }=0.05^{* * *}\end{array}$ & None \\
\hline $\begin{array}{l}\mathrm{S}_{20} \\
(14.6-51.3-100)\end{array}$ & $\begin{array}{l}\mathrm{T} \\
\mathrm{P} \\
\mathrm{T} \times \mathrm{P} \\
\mathrm{S}(\mathrm{P}) \\
\mathrm{T} \times \mathrm{S}(\mathrm{P})\end{array}$ & $\begin{array}{l}F_{5,15}=6.43 * * * \\
\boldsymbol{F}_{\mathbf{2 , 3}}=\mathbf{6 . 0 2} \mathbf{n s} \\
F_{10,15}=2.88 * \\
F_{3,15}=2.77 \mathrm{~ns} \\
F_{15,288}=1.61 \mathrm{~ns}\end{array}$ & $\begin{array}{l}\mathrm{R}: \uparrow * * * \\
\mathrm{PR}: \uparrow * * \\
\mathrm{NR}: \leftrightarrow\end{array}$ & $\begin{array}{c}-1.1+0.01(\mathrm{BM})+0.4(\mathrm{RUG}) \\
+0.1(\mathrm{MD})+0.2(\mathrm{SLO})-0.01(\mathrm{LB}) \\
R^{2} \mathrm{adj}=0.16^{* * *}\end{array}$ & $\begin{array}{l}5.9 * * * \\
6.3 \mathrm{~ns} \\
3.3 * * \\
1.6 \mathrm{~ns} \\
1.7 *\end{array}$ \\
\hline $\begin{array}{l}\mathrm{D}_{20} \\
(17.4-58.1-100)\end{array}$ & $\begin{array}{l}\mathrm{T} \\
\mathrm{P} \\
\mathrm{T} \times \mathrm{P} \\
\mathrm{S}(\mathrm{P}) \\
\mathrm{T} \times \mathrm{S}(\mathrm{P})\end{array}$ & $\begin{array}{l}F_{5,15}=4.58 * * * \\
F_{2,3}=5.17 \mathrm{~ns} \\
F_{10,15}=1.62 \mathrm{~ns} \\
F_{3,15}=1.83 \mathrm{~ns} \\
F_{15,288}=1.37 \mathrm{~ns}\end{array}$ & $\begin{array}{l}\mathrm{R}: \uparrow * * * \\
\mathrm{PR}: \uparrow * * \\
\mathrm{NR}: \leftrightarrow\end{array}$ & $\begin{array}{c}-3.37+1.03(\mathrm{RUG}) \\
R^{2} \mathrm{adj}=0.08^{* * *}\end{array}$ & None \\
\hline
\end{tabular}

TABle 6. - Palma Marine Reserve. Post hoc analysis results from the Student-Newman-Keuls test for a significance level of $P=0.05$.

\begin{tabular}{lc}
\hline Indicator & St \\
\hline Sampling Time & (PR=NR) $>$ R \\
Time 1 & $\mathrm{R}=\mathrm{PR}=\mathrm{NR}$ \\
Time 2 & $\mathrm{R}=\mathrm{PR}=\mathrm{NR}$ \\
Time 3 & (R=PR) $>\mathrm{NR}$ \\
Time 4 & $\mathrm{R}=\mathrm{PR}=\mathrm{NR}$ \\
Time 5 & $\mathrm{R}>(\mathrm{PR}=\mathrm{NR})$ \\
Time 6 & $\mathrm{P}$ \\
\hline
\end{tabular}

than $5.2 \%$ of the variation in any case, which is within the limits caused by sampling error (Table 7).

\section{Carrying capacity in the three no-take areas}

In the FMR the three functions which contain an asymptotic parameter explained more than $70 \%$ of the variation in $\mathrm{Bt}$ (Table 8). The best-fit-logistic function was the function that fitted the temporal trend of the data most accurately, explaining 50\% more variation than the linear and exponential functions at R1 and $30 \%$ more at $\mathrm{R} 2$. The carrying capacity was reached after 7.9 years at $\mathrm{R} 1$, with a value of $\mathrm{K}=6931.2 \pm 736.4 \mathrm{~g} 250 \mathrm{~m}^{-2}$, and af-

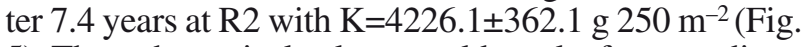
$5)$. These theoretical values would result after a readjustment of $\mathrm{Bt}$ at $\mathrm{R} 1$ provided that the $\mathrm{K}$ value had already been exceeded in the fourth year. At $\mathrm{R} 2, \mathrm{~K} \pm$ se did not significantly differ from the mean $\mathrm{Bt}$ values observed between the third and fourth years $(t=0.387 ; P>0.65)$.

In Palma, the best-fit logistic function explained the most variation in the data for both R1 and R2. As Bt did not differ between the two study sites the combined fit gave a $K=2656.4 \pm 411.9$ after 14.5 years and explained $71 \%$ of the total variation (Table 8 ). These values resulted in a very low accumulated increase in biomass since the fifth year (see Fig. 5, showing an increase of $192 \mathrm{~g}$ in 9.2 years), up to the point where the theoretical $\mathrm{K}$ value did not differ from the mean $\mathrm{Bt}$ value after 5.3 years $(t=0.535 ; P>0.60)$. Therefore, we could argue that the carrying capacity in the Palma notake area was achieved after five years (Fig. 5).

A different temporal trend was observed for Sites 1 and 2 in Menorca (Table 8). The variance explained by the asymptotic functions $\left(R^{2}=0.78-0.79\right)$ at $\mathrm{R} 1$ was very similar to that obtained through linear fitting $\left(R^{2}=0.77\right)$, which did not allow us to determine whether the carrying capacity of the system had already been reached. At $\mathrm{R} 2$, the best-fit logistic curve explained the most variance $\left(R^{2}=0.65\right)$. The $\mathrm{K}$ value at this site was $2394.0 \pm 381.6 \mathrm{~g}$ $250 \mathrm{~m}^{-2}$ after 6.3 years of protection. As in the FMR, this value would result after a readjustment of the biomass observed since the fourth year of closure $(\mathrm{Bt}=2892.5 \pm 405.0)$. 
TABLE 7. - North Menorca MPA. See Table 1 for the explanation of headers

\begin{tabular}{|c|c|c|c|c|c|}
\hline $\begin{array}{l}\text { Indicator and } \\
\text { precision }(\%)\end{array}$ & $\begin{array}{c}\text { Source } \\
\text { of variation }\end{array}$ & $\begin{array}{l}F \text { test, degrees of } \\
\text { freedom and significance }\end{array}$ & Tendence & $\begin{array}{c}\text { Multiple } \\
\text { Regression Equation }\end{array}$ & $\begin{array}{l}\text { ANOVA } \\
\text { for residuals }\end{array}$ \\
\hline $\begin{array}{l}\mathrm{Bt} \\
(12.5-22.7-52.9)\end{array}$ & $\begin{array}{l}\mathrm{T} \\
\mathrm{P} \\
\mathrm{T} \times \mathrm{P} \\
\mathrm{S}(\mathrm{P}) \\
\mathrm{T} \times \mathrm{S}(\mathrm{P})\end{array}$ & $\begin{array}{l}F_{7,21}=10.70 * * * \\
F_{2,3}=1.14 \mathrm{~ns} \\
F_{14,21}=1.54 \mathrm{~ns} \\
F_{3,21}=13.11 * * * \\
F_{21,762}=1.13 \mathrm{~ns}\end{array}$ & 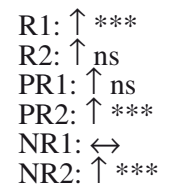 & $\begin{array}{c}353.9+10.2(\mathrm{LB})+315.9(\mathrm{RUG}) \\
R^{2}=0.031^{* * *}\end{array}$ & None \\
\hline $\begin{array}{l}\mathrm{St} \\
(5.9-8.5-17.3)\end{array}$ & $\begin{array}{l}\mathrm{T} \\
\mathrm{P} \\
\mathrm{T} \times \mathrm{P} \\
\mathrm{S}(\mathrm{P}) \\
\mathrm{T} \times \mathrm{S}(\mathrm{P})\end{array}$ & $\begin{array}{l}F_{7,21}=3.55 * * \\
F_{2,3}=6.12 \mathrm{~ns} \\
F_{14,21}=2.10 \mathrm{~ns} \\
F_{3,21}=2.63 \mathrm{~ns} \\
F_{21,762}=1.39 \mathrm{~ns}\end{array}$ & 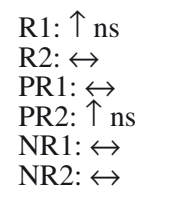 & $\begin{array}{c}2.9+0.18(\mathrm{RUG})-0.01(\mathrm{POSI}) \\
R^{2}=0.02 * * *\end{array}$ & None \\
\hline $\begin{array}{l}\text { Dt } \\
(7.9-16.3-30.6)\end{array}$ & $\begin{array}{l}\mathrm{T} \\
\mathrm{P} \\
\mathrm{T} \times \mathrm{P} \\
\mathrm{S}(\mathrm{P}) \\
\mathrm{T} \times \mathrm{S}(\mathrm{P})\end{array}$ & $\begin{array}{l}F_{7,21}=6.90 * * * \\
F_{2,3}=0.14 \mathrm{~ns} \\
F_{14,21}=1.92 \mathrm{~ns} \\
F_{3,21}=15.79 * * * \\
F_{21,762}=0.86 \mathrm{~ns}\end{array}$ & $\begin{array}{l}\text { R1: } \uparrow * * * \\
\text { R2: } \uparrow \mathrm{ns} \\
\text { PR1: } \leftrightarrow \\
\text { PR2: } \uparrow * \\
\text { NR1: } \leftrightarrow \\
\text { NR2: } \uparrow \mathrm{ns}\end{array}$ & $\begin{array}{c}12.0+0.1(\mathrm{LB})+ \\
+0.1(\mathrm{MB})+1.4(\mathrm{SLO}) \\
R^{2}=0.052^{* * *}\end{array}$ & None \\
\hline$\frac{\underline{S}_{20}}{(8.2-19.3-54.5)}$ & $\begin{array}{l}\mathrm{T} \\
\mathrm{P} \\
\mathrm{T} \times \mathrm{P} \\
\mathrm{S}(\mathrm{P}) \\
\mathrm{T} \times \mathrm{S}(\mathrm{P})\end{array}$ & $\begin{array}{l}F_{7,21}=9.07 * * * \\
F_{2,3}=4.17 \mathrm{~ns} \\
F_{14,21}=1.46 \mathrm{~ns} \\
F_{3,21}=3.68 * \\
F_{21,762}=2.21 * * *\end{array}$ & $\begin{array}{l}\mathrm{R} 1: \uparrow * * \\
\mathrm{R} 2: \uparrow \mathrm{ns} \\
\mathrm{PR} 1: \uparrow \mathrm{ns} \\
\mathrm{PR} 2: \uparrow \mathrm{ns} \\
\mathrm{NR} 1: \leftrightarrow \\
\mathrm{NR} 2: \leftrightarrow\end{array}$ & $\begin{array}{c}0.24+0.03(\mathrm{RUG})+0.02(\mathrm{SLO}) \\
R^{2}=0.02 * * * *\end{array}$ & None \\
\hline$\frac{\underline{D}_{20 *}}{(14.9-29.9-75.1)}$ & $\begin{array}{l}\mathrm{T} \\
\mathrm{P} \\
\mathrm{T} \times \mathrm{P} \\
\mathrm{S}(\mathrm{P}) \\
\mathrm{T} \times \mathrm{S}(\mathrm{P})\end{array}$ & $\begin{array}{l}F_{7,21}=11.36 * * * \\
F_{2,3}=3.54 \mathrm{~ns} \\
F_{14,21}=1.53 \mathrm{~ns} \\
F_{3,21}=4.95 * * \\
F_{21,762}=1.88 * * *\end{array}$ & 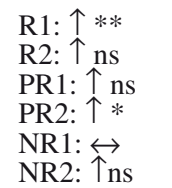 & $\begin{array}{c}0.25+0.03(\mathrm{RUG})+0.001(\mathrm{LB}) \\
R^{2}=0.02 * * * *\end{array}$ & None \\
\hline
\end{tabular}

Freus. Site 1

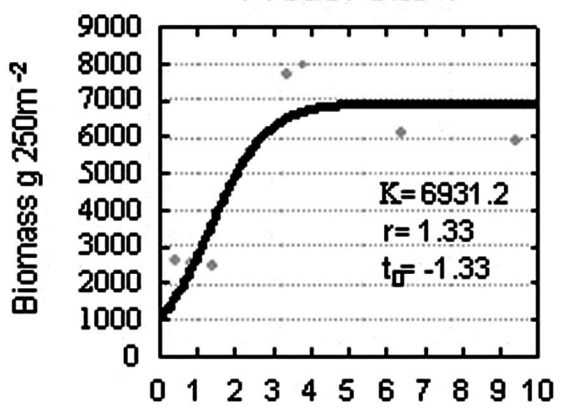

Freus. Site 2

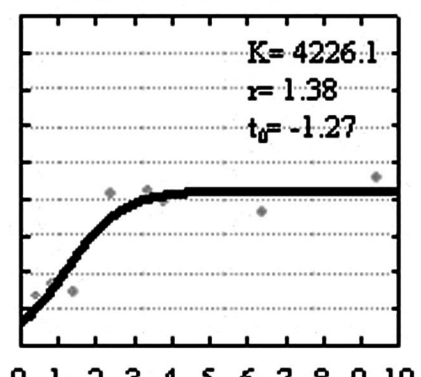

Palma. Sites 1 and 2

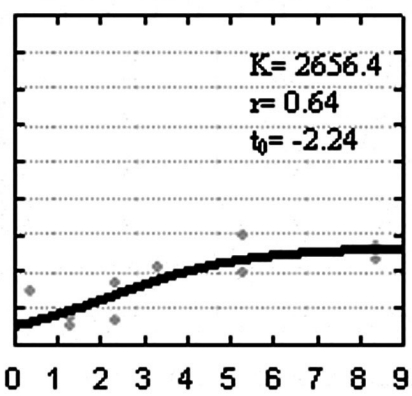

Menorca. Site 1

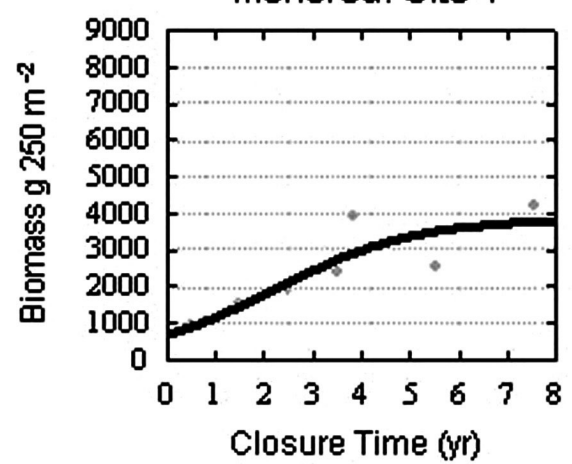

Menorca. Site 2

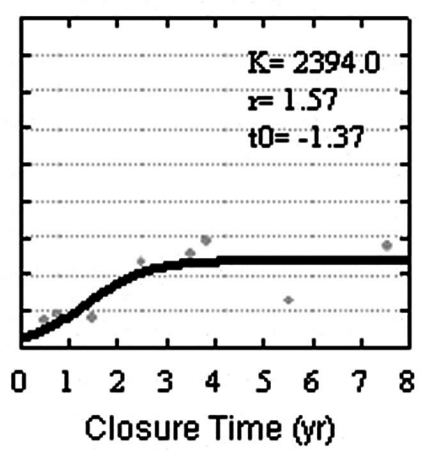

FIG. 5. - Best-fit-logistic curves for mean biomass and closure time at each site in the FMR and NMMR and for both sites in PMR together. 
TABLE 8. - Explained variation $\left(R^{2}\right)$ and significance $(* P<0.05 ; * * P<0.025 ; * * * P<0.01)$ for different models fitted for Bt and protection time at Sites 1 and 2 from the Freus, Palma and North Menorca no-take areas.

\begin{tabular}{|c|c|c|c|c|c|}
\hline MPA/Site & Best-fit logistic & Gompertz & Von Bertalanffy & Linear & Exponential \\
\hline FR1 & $0.83 * * *$ & $0.76 * * *$ & $0.72 * * *$ & $0.33 * * *$ & $0.27 * * *$ \\
\hline FR2 & $0.86 * * *$ & $0.84 * * *$ & $0.81 * * *$ & $0.55 * * *$ & $0.48 * * *$ \\
\hline Palma Sites 1 and 2 & $0.71 * * *$ & $0.69 * * *$ & $0.66 * * *$ & $0.63 * * *$ & $0.57 * * *$ \\
\hline PR1 & $0.91 * * *$ & $0.90 * * *$ & $0.88 * * *$ & $0.88 * * *$ & $0.82 * * *$ \\
\hline PR2 & $0.67 * *$ & $0.64 * *$ & $0.61 * *$ & $0.53 * * *$ & $0.46^{* * *}$ \\
\hline MR1 & $0.78 * * *$ & $0.79 * * *$ & $0.79 * * *$ & $0.77 * * *$ & $0.70 * * *$ \\
\hline MR2 & $0.65 * * *$ & $0.62 * * *$ & $0.59 * * *$ & $0.42 * * *$ & $0.36 * * *$ \\
\hline
\end{tabular}

\section{DISCUSSION}

\section{The effect of time at each protection level}

Time has led to large significant changes in almost all of the indicators in the 3 MPAs. However, site-specific responses and/or sporadic changes at certain control sites (Palma and Menorca) meant that the interaction between time and protection level was not always statistically significant. The analysis of temporal patterns within each protection level and at each site was very helpful to interpret the changes that have occurred.

The indicators that determine the frequency of large individuals $\left(\mathrm{D}_{20}\right.$ and $\left.\mathrm{S}_{20}\right)$ always increased significantly over time in both or one of the completely or partially protected sites in the 3 MPAs. The the most frequent species have become larger over time and the species that were rarer at the beginning of the study have increased in occurrence and size, leading to an increase in biomass and therefore a recovery of the populations of target species in all three MPAs.

The "reserve effect" (García-Rubies and Zabala 1990, Roberts and Polunin 1991, Lester et al. 2009) was most consistent and homogenous at Freus because all the indicators except for Dt showed a significant $\mathrm{T} \times \mathrm{P}$ interaction, with positive trends in the no-take area and in PR2.

The seabed complexity in the no-take FMR is rather low (Table 4). R1 is dominated by flat rock, and in R2 seagrass and detrital sediment define boundaries with the shallow rocky blocks (Ballesteros and Cebrian 2004). The richness of the target fish assemblage was lower in this area than in the control area during the first two years of monitoring. However, although the protection time reversed this trend and significantly increased fish richness, the habitat type of these sites does not favour the establishment of large populations of large carnivores (e.g. large Serranidae) as in other Mediterranean MPAs that have highly complex substrates down to considerable depths (>30 m depth) (Zabala et al. 1997, Reñones et al. 1999, García-Charton et al. 2004). The data on habitat type and rugosity (Table 4) suggest that there are probably very few refuges for these large carnivorous fish. Therefore, with low values for this fish guild, the habitat characteristics of the no-take FMR favour large-sized, long-lived Labridae species of the Labrus genera which feed on invertebrates and small fish. The biomass of these species has increased by two orders of magnitude in the no-take area and by a fac- tor of 3.7 in the partial reserve (Table 3). They are less refuge-dependent than large carnivorous fish and spend most time searching for food over flat rocky seabeds covered with algae and Posidonia. Without doubt the endangered species $L$. merula and $L$. viridis, which are traditionally targeted by trammel nets and spearfishing (Coll et al. 2004, Abdul Malak et al. 2011), are among the most favoured by protection in the no-take FMR.

The quality of the habitat in the no-take area of the Palma reserve is also low for rock fishes, as the sea bottom is dominated by flat rock with some sand and has low seabed rugosity (Table 4). While initially it would seem that the recovery capacity of these seabeds is low, all indicators except Dt have responded positively over time. St significantly increased in the no-take area, although it was conditioned to some extent by the presence of a nearby quality habitat. That is, the average number of species increased per transect only when the seabed rugosity and the presence of rocky blocks made it possible for resident species to appear more frequently. $S_{20}$, which depends to a great extent on fishing mortality, responded positively to protection independently of the complexity of the habitat. This is the same case as that commented above for Labridae, and also for the Sparidae D. sargus, D. vulgaris and D. puntazzo, which feed on algal communities at shallow depths despite the low seabed rugosity of these environments (Sala 1996). The final biomass values around PMR are low $(<3000 \mathrm{~g} 250$ $\mathrm{m}^{-2}$ ) and occasional appearances of schools of D. sargus and/or $D$. vulgaris at control sites led to similar increases in biomass to those observed in the no-take area. However, there is a clearly defined pattern in the no-take area (significant growth regressions for most indicators) that is absent in the controls, which shows that the positive evolution of the indicators in recent years is due to the protection measures.

The state of the resources was very poor in the NMMR at the beginning of the study. Despite the trends of increasing biomass both in R and PR, the differences between the NMMR and the controls were neither high nor significant mainly because of the low initial values in the MPA, possible cases of poaching, fish relocation, and the increase in the resources in NR2. These results clearly show that single once-only protected $v s$ unprotected comparisons can mask positive recovery trends resulting from protection. Although positive responses at control sites are not unheard of in the literature (see Russ et al. 2005, Samoilys et al. 2007, Francini-Filho and Moura 2008), in this case we attribute this result 
to the sampling, particularly in the random placement of transects in a very heterogeneous environment, both in habitats and uses. The census transects in NR2 in recent surveys moved haphazardly towards a bay used intensively for recreational purposes (swimming, pedal boats) that prevent both recreational and professional fishing. There was, in fact, a micro-reserve effect in the bay due to the segregation of uses with significantly different impacts on fish populations, which explains the observed recovery.

The total density of fish (Dt) did not show a $\mathrm{T} \times \mathrm{P}$ interaction in any of the MPAs studied. The fact that this indicator did not respond in a similar way to the others shows that the young fraction (small size) of each population, which without doubt affects the total density, is subject to variations that are independent of protection. The interannual variations between settlement and recruitment or the habitat characteristics at site level, which favour settlement to different degrees, can be as large inside as outside the MPAs (see MacPherson et al. 1997). Moreover, the fisheries regulations outside the MPAs are restrictive enough to protect small fish, especially the most abundant ones (Sparidae), preventing total depletion at these sites. Several studies in both temperate and tropical locations show higher abundances of target species inside than outside no-take areas. However, the effect of protection time on total abundance was not found to be significant (Micheli et al. 2004, Tetreault and Ambrose 2007, Molloy et al. 2009) or was found to act only at species-specific or guild-specific levels (Guidetti and Sala 2007). Most of these studies highlight the importance of analysing biomass when the reserve effect and protection time are tested.

Many studies have described the efficiency and advisability of partially protected marine areas or buffer areas, with the general conclusion that they are fairly inefficient (Denny and Babcock 2004, Claudet et al. 2008, Lester and Halpern 2008, Di Franco et al. 2009). In the present study, the evolution of the resources in the buffer areas was greatly conditioned by the habitat characteristics at each site as well as the current fisheries regulations.

At Freus, the characteristics of FRP1, with low rugosity and few rocky blocks, facilitates fishing with trammel nets very close to the coast. The high fishing pressure (data from the Directorate-General for Fisheries) in this area has probably prevented the recovery of target fish. FRP2 has a more complex seabed, with more rocky blocks and higher rugosity, which makes it difficult to fish with trammel nets. Thus, at this site the Bt has increased by a factor of 3.3 (Fig. 2).

At Palma, Bt did not show a significant increasing pattern inside PR, demonstrating that regulating spearfishing with fishing days and quotas is not effective. Prohibiting fishing for three days a week leaves four days free to practice this recreational activity. This fishing frequency is much higher than that exercised by most recreational fishers in the Balearic Islands (Morales-Nin et al. 2005), and therefore there is no substantial reduction in fishing effort. Moreover, the increasing trends in $\mathrm{S}_{20}$ and $\mathrm{D}_{20}$ in this partially protected area are mainly due to the total protection of PR1 in 2006, two years before the most recent samples were taken (Fig. 3).

The results of the partial reserve in Menorca are considered positive because $\mathrm{Bt}$ has increased by a factor of 2.7 in the two sites together. This positive outcome in a context of active fishing is reinforced by the good results of the grouper longline fishery, which between 2002 and 2006 increased in catch per unit effort by a very similar factor (x3) within the limits of the partial reserve (Coll et al. 2007). The results also extend to other species included in the study by Cardona et al. (2007), who, with a single spatial comparison, found a greater density of omnivorous sparid fish within the NMMR partial reserve than in open fishing areas. Prohibiting spearfishing in complex environments with high rock cover and rugosity favours the groups of species mentioned.

\section{Carrying capacity}

It is noteworthy that $\mathrm{K}$ is a descriptor of current and local conditions and therefore information derived from $\mathrm{K}$ is only applicable to current environmental and faunistic conditions prevailing in the littoral ecosystem. We acknowledge that current conditions cannot be considered those of "pristine biomass" (see comments of McClanahan et al., 2007) or a "pristine level" (Babcock et al., 2010), as in this case a large mammal (monk seal) and three shark species which could naturally be expected to enter and feed in the MPAs are currently locally extinct or endangered (Mayol et al., 2000, Sala 2004). The home range of these species is much greater than that of the studied no-take areas, which would therefore offer them little protection from fishing. However it is important to acknowledge their potential influence, because overriding the K parameter without considering the faunistic history would lead to a shift in the base lines we use (Pauly 1995, Knowlton and Jackson 2008).

Acknowledging that we are referring to the current habitats and environmental conditions, we consider that resources in the no-take areas of FMR and PMR and at site 2 of the NMMR are practically at biomass saturation level. This recovery is likely to have been achieved through a combination of processes. Growth from settlement and recruitment are known to occur predominantly at the shallower sites (MacPherson 1998, Guillanders et al., 2003) and will therefore be an important process at these sites, but would naturally lead to a slower recovery period. This could be the case in the PMR, which has relatively low intrinsic rates of Bt growth $(r<0.7$; Fig. 5). In contrast, immigration of large and often less common fish from deeper waters would lead to a faster path to recovery of the no-take areas. This process is likely to have occurred in the FMR, which has deep neighbouring seabeds and has shown higher rates of intrinsic growth for Bt ( $r>1.3$; Fig. 5). 
Nevertheless, the $\mathrm{K}$ values observed should be interpreted as theoretical references. A first order variation of $\mathrm{K}$ is within the error margins observed $(\mathrm{K} \pm \mathrm{se})$ due to variance at a low spatial scale. Since these are quite accurate ( $<20 \%$ of $K$ in all cases) these $K$ values can be used as reference values with which to assess the resources in other areas of the Balearic coast. Another variation order would be in the time scale. Given that the patterns of recruitment, food availability, immigration/emigration and the phenomena of initial compensation due to low values of adults at the origin (Lorenzen 2008) vary annually within certain margins, $\mathrm{K}$ should be considered as a value that fluctuates over time. Cascade effects due to longer periods of growth for large carnivorous fish and time-lags between fishing mortality changes and community-based indicators could also affect final $\mathrm{K}$ values (Shephard et al., 2011). In this context, Babcock et al. (2010) showed that the target species returned to their former (sic) level in about five years in both temperate and tropical marine reserves. However, once this state was achieved, the resources did not always remain constant but rather increased or decreased periodically. These patterns have not yet been observed in Balearic MPAs.

The general biomass saturation observed in the notake areas dealt with here is in accordance with many studies that describe a quick recovery of the resources, from 3 to 5 years (Cotê et al. 2001, Halpern and Warner 2002, Babcock et al. 2010), or, in a broader time frame, within the first 10 years (Micheli et al. 2004, McClanahan et al. 2009 and McClanahan et al. 2007 for some species). Our results, however, are not in line with the recovery predictions on a longer time scale, as some studies predict that more than 10 years or even human intergenerational periods are needed for resources to recover (McClanahan 2000, Russ and Alcalà 2004, García-Charton et al. 2008, Molloy et al. 2009). For example, Guidetii and Sala (2007) stated that none of the 12 marine reserves studied through meta-analysis in the western Mediterranean, with protection times between 1 and 18 years, had yet reached full recovery. However, these authors compared the differences in density inside and outside the reserve, an approach that can mask the real extent of recovery of the protected area. They suggest that the specific response of each reserve to the protection time depends on local physical and biological factors.

Without doubt local factors affect the six fully protected sites studied here, as they show idiosyncratic recoveries: different $\mathrm{K}$ values, different times to reach them and no clear saturation at R1 in the NMMR. These different $\mathrm{K}$ values or recovery patterns demonstrate the importance of local factors and also show that we are not dealing with a system that protects hot spots but rather one that protects parts of the coast that are representative of the general coastal environment of the Balearic Islands. Although we should keep in mind that our Bt data corresponds to a "reduced biomass" (from discrete group censusing), the $\mathrm{K}$ values of the
Balearic MPAs are lower than biomass values given for other western Mediterranean MPAs. FR1, with its $27.6 \mathrm{t} \mathrm{km}^{-2}$, is the only site that can be compared with the values obtained by García-Charton et al. (2004) for the same group of species in 4 MPAs: $25.6 \mathrm{t} \mathrm{km}^{-2}$ in Cabrera National Park, $27.6 \mathrm{t} \mathrm{km}^{-2}$ in the Cabo de Palos Marine Reserve, $32.4 \mathrm{t} \mathrm{km}^{-2}$ in the Cabo de Gata Marine Reserve; however, it is far from the $103.6 \mathrm{t}$ $\mathrm{km}^{-2}$ found in the offshore Columbretes Islands Marine Reserve. In fact, most of these MPAs can be considered as unique systems, created in areas with structurally complex seascapes that form favourable habitats for the development of rich and abundant reef fish fauna (García-Charton and Pérez-Ruzafa 1999).

Overall, the first three fishery MPAs created in 1999 in the Balearic Islands show positive results in the recovery of important fish assemblages, with a considerable increase in the number of large fish and growing diversity in the no-take areas within the first five years of protection. The partially protected areas were also observed to be effective if there is a quality habitat and the fishing gears that are prohibited are those that are most effective in this habitat (e.g. trammel net for low topography seabeds and spearfishing for highly complex habitats). Future studies should focus on analysing the factors that lead to different carrying capacities, whether they are bottom-up processes due to bottlenecks (sensu Caddy 2008) in the system itself, or top-down processes (e.g. poaching or fishing the line) in which corrective management measures can intervene. In this context, the evolution of the resources should be investigated in deeper waters, where adult fish can reach larger sizes (Gillanders et al. 2003, Palumbi 2004). In deeper waters fish populations can be expected to need longer time periods to recover, which would be more in line with the predictions of Guidetti and Sala (2007) and García-Charton et al. (2008), and more consistent with the life span of key target species (e.g. 65 yr for E. marginatus, 16 yr for $S$. umbra and $>19$ yr for $L$. merula). These predictions would be in accordance with the study by Stobart et al. (2009), who show that a stable state had not yet been reached for deep waters $(50-80 \mathrm{~m})$ after 16 years of protection in the Columbretes Islands Marine Reserve.

\section{ACKNOWLEDGEMENTS}

This paper is a result of IFOP and FEP projects funded by the EU between 2000 and 2009 for the development of MPAs in the Balearic Islands. All field work was carried out with the collaboration of the MPA rangers: P. Arbona, D. García, J. Asensio, A. Martin, Y.B. Chastaing, J. Jiménez, E. Costa, P. Quesada, J. Gelabert, I. Maggiuli, D. Mascaró, D. López Luna, F. Fernández and C. Alonso, all of them coordinated by $\mathrm{O}$. Navarro, who also took part in a great number of visual censuses. To all of them, our most sincere gratitude. We also thank our colleagues B. Hereu, E. Cebrián, M. Palmer, B. Stobart and E. Ballesteros for their contribution at some stages of the project. 


\section{REFERENCES}

Abdul Malak D., Livingstone S.R., Pollard D., Polidoro B.A., Cuttelod A., Bariche M., Bilecenoglu M., Carpenter K.E., Collette B.B., Francour P., Goren M., Hichem Kara M., Massutí E., Papaconstantinou C., Tunesi L. 2011. Overview of the conservation status of the marine fishes of the Mediterranean sea. Gland, Switzerland and Malaga, Spain: IUCN. vii + 61 pp.

Abdulla A., Gomei M., Maison E., Piante C. 2008. Status of Marine Protected Areas in the Mediterranean Sea. IUCN, Málaga and WWF, France. $152 \mathrm{pp}$

Agardi T. 2005. Global marine conservation policy versus site-level implementation: the mismatch of scale and its implications. Mar. Ecol. Prog. Ser. 300: 242-248.

Angulo-Valdes J.A., Hatcher B.C. 2010. A new typology of benefit derived from marine protected areas. Mar. Policy. 34: 635-644.

Babcock R.C., Shears N.T., Alcala A., Barret N.S., Edgar G.J., Lafferty K.D., McClanahan T.R., Russ G.R. 2010. Decadal trends in marine reserves reveal differential rates of change in direct and indirect effects. PNAS. 107: 18256-18261.

Ballesteros E., Cebrian E. 2004. Estudi sobre la bionomia bentònica, biodiversitat $i$ cartografía de les reserves marines dels Freus entre Eivissa i Formentera, de la badia de Palma i del Nord de Menorca. Informe tècnic del Centre d'estudis Avançats de Blanes-CSIC. 3 volums. 330 pp.

Barret N.S., Edgar G.J., Buxton C.D., Haddon M. 2007. Changes in fish assemblages following 10 years of protection in Tasmanian marine protected area. J. Exp. Mar. Biol. Ecol. 345: 141-157.

Bell J.D., Craik G.J.S., Pollard D.A., Russell B.C. 1985. Estimating length frequency distributions of large reef fish underwater. Coral Reefs. 4: 41-44.

Berkeley S.A., Hixon M.A., Larson R.J., Love M.S. 2004. Fisheries sustainability via protection of age structure and spatial distribution of fish populations. Fisheries. 29: 23-32.

Caddy J.F. 2008. The importance of "cover" in the life histories of demersal and benthic marine resources: a neglected issue in fisheries assessment and management. Bull. Mar. Sci. 83: 7-52.

Caddy J.F., Mahon R. 1995. Reference points for fisheries management. FAO Fisheries Technical Paper. No. 347. Rome, FAO, $83 \mathrm{pp}$.

Cardona L. 2002. Biogeografia. In: Obra Cultural de Menorca (eds.), Enciclopèdia de Menorca, Tom Cinquè. Vertebrats. Volum 2: peixos, amfibis i rèptils. Maó, Spain.

Cardona L., Sales M., López D. 2007. Changes in fish abundance do not cascade to sea urchins and erect algae in one of the most oligotrophic parts of the Mediterranean. Est. Coast. Shelf Sci. 72: 273-282.

Clark C.W. 1990. Mathematical bioeconomics. The optimal management of renewable resources. $2^{\text {nd }}$ ed. A wiley-Interscience publication. Bers L., Hilton P., Hochstadt H., Lax P., Toland J. (eds).

Claudet J., Osemberg C.W., Benedetti-Cecchi L., Domenici P., García-Charton J.A., Pérez-Ruzafa A., Badalamenti F., BayleSempere J., Brito A., Bulleri F., Culioli J-M., Dimech M., Falcón J.M., Guala, I., Milazzo M., Sánchez.Meca J., Somerfield P.J., Stobart B., Vandeperre F., Valle C., Planes S. 2008. Marine reserves: size and age do matter. Ecol. Lett. 11: 481-489.

Coll J., Garcia-Rubies A., Morey G., Navarro O., Martino S., Riera F., Grau A.M. 2007. The North of Minorca Marine Reserve (W Mediterranean) as a tool for a sustainable management of natural resources. The case of the dusky grouper Epinephelus marginatus (Lowe, 1834). In: Francour P., Gratiot J. (eds.), $2^{\text {nd }}$ Symposium on Mediterranean Groupers. Nice, May $10^{\text {th }}-13^{\text {th }} 2007$, pp. 55-57.

Coll J., Linde M., García-Rubies A., Riera F., Grau A. M. 2004. Spear fishing in the Balearic Islands: species affected and catch evolution during the period 1975-2001. Fish. Res. 70: 97-111.

Côté I. M., Mosqueira I., Reynolds J. D. 2001. Effects of marine reserve characteristics on the protection of fish populations: a metaanalysis. J. Fish Biol. 59: 178-189.

Chapman M. R., Kramer D. L. 1999. Gradients in coral reef fish density and size across the Barbados Marine Reserve boundary: effects of reserve protection and habitat characteristics. Mar. Ecol. Prog. Ser. 181: 81-96.

Denny C.M., Babcock R.C. 2004. Do partial marine reserves protect reef fish assemblages? Biol. Conserv. 116: 119-129.

Di Franco A., Bussotti S., Navone A., Panzalis P., Guidetti P. 2009. Evaluating effects of total and partial restrictions to fishing on
Mediterranean rocky-reef assemblages. Mar. Ecol. Prog. Ser. 387: 275-285.

FAO 1995. The state of world fisheries and aquaculture. Special publication for the $21^{\text {st }}$ session of the committee of fisheries, FAO (eds.) March 1995, Rome, Italy.

Forcada A., Valle C., Bonhomme P., Criquet G., Cadiou G., Lenfant P., Sánchez-Lizaso J.L. 2009. Effects of habitat on spillover from marine protected areas to artisanal fisheries. Mar. Ecol. Prog. Ser. 379: 197-211.

Francini-Filho R.B., Moura R.L. 2008. Dynamics of fish assemblages on coral reefs subjected to different management regimes in the Abrolhos Bank, eastern Brazil. Aquat Conserv: Mar. Freshw. Ecosyst. 18: 1166-1179.

Froese R., Pauly D. 1999. FishBase 99: conceptos, estructura y fuentes de datos. ICLARM (eds.), Manila, Filipinas, $322 \mathrm{pp}$

García-Charton J.A., Pérez-Ruzafa A. 1999. Ecological heterogeneity and the evaluation of the effects of marine reserves. Fish. Res. 42: $1-20$.

García-Charton J.A., Pérez-Ruzafa A., Sánchez-Jerez P., BayleSempere J-T., Reñones O., Moreno D. 2004. Multi-scale spatial heterogeneity, habitat structure, and the effect of marine reserves on Western Mediterranean rocky reef fish assemblages. Mar. Biol. 144: 161-182.

García-Charton J.A., Pérez-Ruzafa A., Marcos C., Claudet J., Badalamenti F., Benedetti-Cecchi L., Falcon J.M., Milazzo M., Schembri P.J, Stobart B., Vandeperre F., Brito A., Chemello R., Dimech M., Domenici P., Guala I., Le Diréach L., Maggi E., Planes S. 2008. Efectiveness of European Atlanto-Mediterranean MPAs: Do they accomplish the expected effects on populations, communities and ecosystems? J. Nat. Conserv. 16: 193-221.

Garcia-Rubies A., Zabala M. 1990. Effects of total fishing prohibition on the rocky fish assemblages of Medes Islands marine reserve (NW Mediterranean). Sci. Mar. 54: 317-328.

Gillanders B.M., Able K.W., Brown J.A., Eggleston D.B., Sheridan P.F. 2003. Evidence of connectivity between juvenile and adult habitats for mobile marine fauna: an important component of nurseries. Mar. Ecol. Prog. Ser. 247: 281-295.

Goñi R., Adlerstein S., Álvarez-Berastegui D., Forcada A., Reñones O., Criquet G., Polti S., Cadiou G., Valle C., Lenfant P., Bonhomme P., Pérez-Ruzafa A., Sánchez-Lizaso J.L., García-Charton J.A., Bernard G., Stelzenmüller V., Planes S. 2008. Spillover from six western Mediterranean marine protected areas: evidence from artisanal fisheries. Mar. Ecol. Prog. Ser. 366: 159-174.

Greene L.E., Alevizon W.S. 1989. Comparative accuracies of visual assessment methods for coral reef fishes. Bull. Mar. Sci. 44: 899-912.

Grüss A., Kaplan D.M., Guénette S., Roberts C.M., Botsford L.W. 2011. Consequences of adult and juvenile movement for marine protected areas. Biol. Conserv. 144: 692-702.

Guidetti P., Sala E. 2007. Community-wide effects of marine reserves in the Mediterranean Sea. Mar. Ecol. Prog. Ser. 335: 43-56.

Guidetti P., Milazzo M., Bussotti S., Molinari A., Murenu M., Pais A., Spano N., Balzano R., Agardy T., Boero F., Carrada G., Cattaneo-Vietti R., Cau A., Chemello R., Greco S., Manganaro A., Notarbartolo Di Sciara G., Russo G.F., Tunessi L. 2008. Italian marine reserve effectiveness: Does enforcement matter? Biol. Conserv. 141: 699-709.

Halpern B.S., Warner R.R. 2002. Marine Reserves have rapid and lasting effects. Ecol. Lett. 5: 361-366.

Harmelin J-G. 1987. Structure et variabilité de l'ichtyofaune d'une zone rocheuse protegée en Méditerrannée (Parc national de port Cros, France). P.S.Z.N.I: Mar. Ecol. 8: 263-284.

Harmelin-Vivien M., Le Diréach L., Bayle-Sempere J., Charbonnel E., García-Charton J.A, Oddy D., Pérez-Ruzafa A., Reñones O., Sánchez-Jerez P., Valle C. 2008. Gradients of abundance and biomass across reserve boundaries in six Mediterranean marine protected areas: evidence of spillover? Biol. Conserv. 141: 1829-1839.

Jackson J.B.C. 2001. What was natural in the coastal oceans? PNAS. 98: 5411-5418.

Jennings S. 2001. Patterns and prediction of population recovery in marine reserves. Rev. Fish Biol. Fish. 10: 209-231.

Kaufmann K.W. 1981. Fitting and using growth curves. Oecologia, 49: 293-299.

Knowlton N., Jackson J.B.C. 2008. Shifting baselines, local impacts, and global change on coral reefs. PLoS Biol. 6: e54, 0215-0220.

Lester S.E., Halpern B.S. 2008. Biological responses in marine no- 
take reserves versus partially protected areas. Mar. Ecol. Prog. Ser. 367: 49-56.

Lester S.E., Halpern B.S., Grorud-Colvert K., Lubchenco J., Ruttenberg B.I., Gaines S.D., Airamé S., Warner R.R. 2009. Biological effects within no-take marine reserves: a global synthesis. Mar. Ecol. Prog. Ser. 384: 33-46.

Lorenzen K. 2008. Fish population regulation beyond "stock and recruitment": the role of density-dependent growth in the recruited stock. Bull. Mar. Sci. 83: 181-196.

Luckhurst B.E., Luckhurst K. 1978. Analysis of the Influence of Substrate Variables on Coral Reef Fish Communities. Mar. Biol. 49: 317-323.

Macpherson E. 1998. Ontogenetic shifts in habitat use and aggregation in juvenile sparid fishes. J. Exp. Mar. Biol. Ecol. 220: 127-150.

Macpherson E., Biagi F., Francour P., Garcia-Rubies A., Harmelin J-G., Harmelin-Vivien M., Jouvenel J.Y., Planes S., Vigliola L., Tunesi L. 1997. Mortality of juvenile fishes of the genus Diplodus in protected and unprotected areas in the western Mediterranean Sea. Mar. Ecol. Prog. Ser. 160: 135-147.

Mayol J., Grau A.M., Riera F., Oliver J. 2000. Llista vermella dels peixos de les Balears. Quadern de Pesca ${ }^{\circ} 4$, Conselleria d'Agricultura i Pesca. Govern de les Illes Balears (eds.). Palma de Mallorca. Spain, $126 \mathrm{pp}$.

McClanahan T.R. 2000. Recovery of a coral reef keystone predator, Balistapus undulatus, in East African marine parks. Biol. Conserv. 94: 191-198.

McClanahan T.R., Arthur R. 2001. The effect of marine reserves and habitat on populations of east African coral reef fishes. Ecol. Appl. 11: 559-569.

McClanahan T.R., Graham N.A.J., Calnan J.M., Macneil M.A. 2007. Toward pristine biomass: Reef fish recovery in coral reef marine protected areas in Kenya. Ecol. Appl. 17: 1055-1067.

McClanahan T.R., Graham N.A.J., Wilson S.K., Letourneur Y., Fisher R. 2009. Effects of fisheries closure size, age, and history of compliance on coral reef fish communities in the western Indian Ocean. Mar. Ecol. Prog. Ser. 396: 99-109.

Micheli F., Halpern B.S., Botsford L.W., Warner R.R. 2004. Trajectories and correlates of community change in no-take marine reserves. Ecol. Appl. 14: 1709-1723.

Molloy P., McLean I.B., Côté I.M. 2009. Effects of marine reserve age on fish populations: a global meta-analysis. J. Appl. Ecol. 46: 743-751.

Mora C., Myers R.A., Coll M., Libralato S., Pitcher T.J., Sumaila R.U., Zeller D., Watson R., Gaston K.J., Worm B. 2009. Management effectiveness of the world's marine fisheries. PLoS Biol. 7: e1000131.

Morales-Nin B., Moranta J., García C., Tugores M.P., Grau A.M., Riera F., Cerdà M. 2005. The recreational fishery off Majorca Island (western Mediterranean): some implications for coastal management. ICES J. Mar. Sci. 62: 727-739.

Morey G., Moranta J., Massuti E., Grau A., Linde M., Riera F., Morales-Nin B. 2003. Weight-length relationship of littoral to lower slope fishes from the western Mediterranean. Fish. Res. 62: 89-96.

Ordines F., Moranta J., Palmer M., Lerycke A., Suau A., Morales-Nin B., Grau A.M. 2005. Variations in a shallow rocky reef fish community at different spatial scales in the western Mediterranean Sea. Mar. Ecol. Prog. Ser. 304: 221-233.

Palumbi S.R. 2004. Marine reserves and ocean neighborhoods: the spatial scale of marine populations and their management. Аппи. Rev. Environ. Resour. 29: 31-68.

Pauly D. 1984. Fish population dynamics in tropical waters: a manual for use with programmable calculators. ICLARM Stud. Rev. 8. 325 pp.

Pauly D. 1995. Anecdotes and shifting baseline syndrome of fisheries. TREE. 10: 430

Plan Development Team. 1990. The potential of Marine Fishery Reserves for reef fish management in the U.S Southern Atlantic. NOAA Technical Memorandum. NMFS-SEFC 261: 1- 40, USA.

Reñones O., Goñi R., Pozo M., Deudero S. 1999. Effects of the cessation of fishing in protected areas of the Cabrera Archipelago National Park. Results of species of the Serranidae and Sparidae families. In: $1^{\text {st }}$ International Workshop on Marine Reserves, Murcia (Spain).

Reñones O., Goñi R., Pozo M., Deudero S., Moranta J. 1998. Effects of protection on the demographic structure and abundance of
Epinephelus marginatus (Lowe, 1834). Evidence from Cabrera Archipelago National Park (West-central Mediterranean). In Mémoires de l'Institut océanographique Paul Ricard. Symposium International sur les Mérous de Méditerranée, novembre 1998, Embiez, France, pp. 155-164.

Reñones O., Grau A., Mas X., Riera F., Saborido-Rey F. 2010. Reproductive pattern of an exploited dusky grouper Epinephelus marginatus (Lowe, 1834) (Pisces: Serranidae) population in the western Mediterranean. Sci. Mar. 74: 523-537.

Roberts C.M., Polunin N.V.C. 1991. Are marine reserves effective in management of reef fisheries? Rev. Fish Biol. Fish. 1: 65-91.

Russ G.R., Alcala A.C. 1996. Do marine reserves export adult fish biomass? Evidence from Apo Island, central Philippines. Mar. Ecol. Prog. Ser. 132: 1-9.

Russ G.R., Alcala A.C. 2004. Marine reserves: long-term protection is required for full recovery of predatory fish populations. Oecologia, 138: 622-627.

Russ G.R., Stockwell B., Alcala A.C. 2005. Inferring versus measuring rates of recovery in no-take marine reserves. Mar. Ecol. Prog. Ser. 292: 1-12.

Sala E. 1996. The role of fishes in the organisation of a Mediterranean sublitoral community. $\mathrm{PhD}$ thesis. Université d'AixMarseille II. Marseille. France. 174 pp.

Sala E. 2004. The past and present topology and structure of Mediterranean subtidal rocky-shore food webs. Ecosystems, 7: 333-340.

Samoilys M., Carlos G. 1992. Development of an underwater visual census method for assessing shallow water reef fish stocks in the south west Pacific. In: Queensland Department of Primary Industries Northern Fisheries Centre (eds.) PO Box 5396 Cairns Queensland 4870 Australia. 99 pp.

Samoilys M.A., Martin-Smith K.M, Giles B.G., Cabrera B., Anticamara J.A., Brunio E.O., Vincent A.C.J. 2007. Effectiveness of five small Philippines' coral reef reserves for fish populations depends on site-specific factors, particularly enforcement history. Biol. Conserv. 136: 584-601.

Sánchez-Lizaso J.L., Goñi R., Reñones O., García-Charton J.A., Galzin R., Bayle J.T, Sánchez-Jerez P., Pérez-Ruzafa A., Ramos A.A. 2000. Density dependence in marine protected populations: a review. Env. Conserv. 27: 144-158.

Shephard S., Reid D.G., Greenstreet S.P.R. 2011. Interpreting the large fish indicator for the Celtic Sea. ICES J. Mar. Sci. 68 1963-1972.

Stobart B., Warwick R., González C., Mallol S., Díaz D., Reñones O., Goñi R. 2009. Long-term and spillover effects of a marine protected area on an exploited fish community. Mar. Ecol. Prog. Ser. 384: 47-60.

Tetreault I., Ambrose R.F. 2007. Temperate marine reserves enhance targeted but not untargeted fishes in multiple no-take MPAs. Ecol. Appl. 17: 2251-2267.

Underwood A.J. 1997. Experiments in ecology. Their logical design and interpretation using analysis of variance. Cambridge University Press, United Kingdom, 504 pp.

White A.T., Aliño P.M., Meneses A.T. 2006. Creating and managing marine protected areas in the Philippines-Fisheries. Improved for Sustainable Harvest Project. Philippines Marine Science Institute. Coastal Conservation and Education Foundation, Inc. University of the Philippines Marine Science Institute, Cebu City, 83 pp.

Wood L.J., Fish L., Laughren J., Pauly D. 2008. Assessing progress towards global marine protection targets: shortfalls in information and action. Oryx 42: 340-351.

Worm B., Barbier E.B., Beaumont N., Duffy J.E., Folke C., Halpern B.S., Jackson J.B.C., Lotze H.K., Micheli F., Palumbi S.R., Sala E., Selkoe K.A., Stachowicz J.J., Watson R. 2006. Impacts of biodiversity loss on ocean ecosystem services. Science 314 787-790.

Zabala M., Lousy P., Garcia-Rubies A., Gracia V. 1997. Socio-behavioural context of reproduction in the Mediterranean dusky grouper Epinephelus marginatus (Lowe, 1834) (Pisces, Serranidae) in the Medes Islands Marine Reserve (NW Mediterranean, Spain). Sci. Mar. 61: 79-89.

Zar J.H. 1984. Biostatistical Analysis. Prentice Hall, Inc. New Jersey.

Scient. ed.: V. Stelzenmüller.

Received November 2, 2011. Accepted March 28,2012.

Published online August 2, 2012. 